\title{
Jellyfish fisheries in the Americas: origin, state of the art, and perspectives on new fishing grounds
}

Article in Reviews in Fish Biology and Fisheries · September 2016

DOI: 10.1007/s11160-016-9445-y

CITATION

1

12 authors, including:
READS

\section{Juana LOPEZ Martinez}

Centro de Investigaciones Biológicas del Nor.. 98 PUBLICATIONS 635 CITATIONS

SEE PROFILE

\section{Javier Quiñones}

Instituto del Mar del Perú

20 PUBLICATIONS 260 CITATIONS

SEE PROFILE

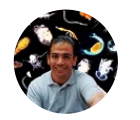

Francisco Javier Alvarez Tello 8 PUBLICATIONS 9 CITATIONS

SEE PROFILE

\section{André C. Morandini}

University of São Paulo

92 PUBLICATIONS 785 CITATIONS

SEE PROFILE

Some of the authors of this publication are also working on these related projects: 


\title{
Jellyfish fisheries in the Americas: origin, state of the art, and perspectives on new fishing grounds
}

\author{
Lucas Brotz $\mathbb{D} \cdot$ Agustín Schiariti · Juana López-Martínez • Javier Álvarez-Tello • \\ Y.-H. Peggy Hsieh · Robert P. Jones · Javier Quiñones • Zhijun Dong • \\ André C. Morandini · Mercy Preciado · Enrique Laaz · Hermes Mianzan
}

Received: 17 November 2015/ Accepted: 10 September 2016

(C) Springer International Publishing Switzerland 2016

\begin{abstract}
Jellyfish (primarily scyphomedusae) fisheries have a long history in Asia, where jellyfish have been caught and processed as food for centuries. More recently, jellyfish fisheries have expanded to the Western Hemisphere, often driven by demand from Asian buyers and collapses of more traditional local fish stocks. Jellyfish fisheries have been attempted in numerous countries in North, Central, and South America, with varying degrees of success. Here, we chronicle the arrival of jellyfish fisheries in the
\end{abstract}

Hermes Mianzan: Deceased.

L. Brotz $(\square)$

Sea Around Us, Institute for the Oceans and Fisheries,

University of British Columbia, Vancouver,

British Columbia, Canada

e-mail: lucasbrotz@gmail.com

A. Schiariti · H. Mianzan

Instituto Nacional de Investigación y Desarrollo Pesquero

(INIDEP), Mar del Plata, Buenos Aires, Argentina

\begin{abstract}
A. Schiariti
Instituto de Investigaciones Marinas y Costeras (IIMyC), CONICET, Universidad Nacional de Mar del Plata,

Mar del Plata, Buenos Aires, Argentina
\end{abstract}

J. López-Martínez · J. Álvarez-Tello

Centro de Investigaciones Biológicas del Noroeste,

La Paz, Baja California Sur, Mexico

Y.-H. Peggy Hsieh

Department of Nutrition, Food and Exercise Sciences,

Florida State University, Tallahassee, Florida, USA
Americas and summarize relevant information on jellyfish fishing, processing, and management. Processing technology for edible jellyfish has not advanced, and presents major concerns for environmental and human health. The development of alternative processing technologies would help to eliminate these concerns and may open up new opportunities for markets and species. We also examine the biodiversity of jellyfish species that are targeted for fisheries in the Americas. Establishment of new jellyfish fisheries appears possible, but requires a specific combination of factors including high

\author{
R. P. Jones \\ Southeastern Fisheries Association, Tallahassee, Florida, \\ USA \\ J. Quiñones \\ Laboratorio Costero de Pisco, Instituto del Mar del Perú \\ (IMARPE), Paracas, Ica, Peru
}

\section{Z. Dong \\ Key Laboratory of Coastal Zone Environmental Processes and Ecological Remediation, Yantai Institute of Coastal Zone Research, Chinese Academy of Sciences, Yantai, Shandong, China}

\author{
A. C. Morandini \\ Departamento de Zoologia, Instituto de Biociências, \\ Universidade de São Paulo (USP), São Paulo, São Paulo, \\ Brazil \\ M. Preciado - E. Laaz \\ Instituto Nacional de Pesca, Guayaquil, Guayas, Ecuador
}


abundances of particular species, processing knowledge dictated by the target market, and either inexpensive labor or industrialized processing facilities. More often than not, these factors are not altogether evaluated prior to attempting a new jellyfish fishery. As such, jellyfish fisheries are currently expanding much more rapidly than research on the subject, thereby putting ecosystems and stakeholders' livelihoods at risk.

Keywords Jellies · Jellyfish fishery ·

Scyphomedusae $\cdot$ Scyphozoa $\cdot$ Zooplankton fisheries . Gelatinous zooplankton

\section{Introduction}

Jellyfish (herein referring to members of the Phylum Cnidaria with a pelagic phase, primarily in the Class Scyphozoa) are notorious for interfering with human activities and industries including fisheries, aquaculture, and tourism (Purcell et al. 2007; Lucas et al. 2014). However, jellyfish (or 'medusae') are also acclaimed for their utilization as food in Asia. The Chinese have savored jellyfish for centuries as cuisine to be served regularly, as well as on special occasions such as holidays, weddings, and celebrations (Hsieh and Rudloe 1994). Consumption of jellyfish is also popular in Asian countries other than China, including Japan, Malaysia, Korea, Taiwan, Singapore, and other nations where there is strong market demand (Kingsford et al. 2000; Hsieh et al. 2001; Omori and Nakano 2001). Interestingly, cnidarians were also consumed in ancient Rome, as indicated by the Latin cookbook Apicius (Vehling 1977), but whether the "sea nettles" referred to in the text are indeed jellyfish or rather sessile anemones remains unresolved. Regardless, it is amusing to note that the recipe suggests that when the cnidarians are served atop of eggs in a type of omelette, "no one at the table will know what they are eating" (Grocock and Grainger 2006).

Chinese emigrants likely first introduced jellyfish fisheries to Southeast Asia. Countries such as Malaysia and Indonesia appear to have established jellyfish fisheries around the middle of the twentieth century, with Thailand and the Philippines following suit in the 1970s. Additional Asian countries have initiated jellyfish fisheries in recent decades, including
Myanmar, Vietnam, India, Sri Lanka, and Russia (Brotz 2016). To keep up with demand, jellyfish fisheries have also spread to the Western Hemisphere, often preceded by local collapses of more traditional fisheries resources. While jellyfish fisheries have been explored in at least eight countries in North, Central, and South America, the degree to which jellyfish fisheries have successfully established in the Americas varies (Table 1; Fig. 1). Most consumption continues to be in Asia, with the majority of the traded product being exported to China, Japan, and South Korea (Huang 1986, 1988; Hsieh and Rudloe 1994; Omori and Nakano 2001; Kitamura and Omori 2010).

Jellyfish fisheries are typically characterized by large interannual fluctuations in abundance and biomass, short fishing seasons of usually less than a few months, as well as limited research and management. These circumstances can cause instability of jellyfish fisheries and may prevent fishers, stakeholders, and policy-makers from supporting development. In addition, the species being targeted have complex life cycles including both pelagic (medusa) and benthic (polyp) stages, making it difficult to model and predict population dynamics and responses to fishing pressure. While jellyfish catches are reported by the Food and Agriculture Organization of the United Nations (FAO), the data are not reliable. Many countries do not report their jellyfish catches explicitly, including them as either miscellaneous invertebrates or not at all. In fact, catches of jellyfish as food for humans are significant, with global landings recently exceeding 1 million tonnes (Brotz 2016; Brotz and Pauly 2016). The catch from jellyfish fisheries in the Americas is still relatively small compared to that from Asia, comprising only about $3 \%$ of the global catch (Brotz 2016). Nonetheless, the geographical expansion of jellyfish fisheries is real, albeit with mixed results regarding successful establishment. The consequences of this expansion remain unclear for fishers and ecosystems, as scientific studies are not keeping pace. As such, we aim to discuss some of the relevant issues regarding jellyfish fisheries in the Americas, including where jellyfish are being caught, how much is landed, and which species are being targeted. We also review knowledge and diversity of rhizostome jellyfish in the Americas, the potential impacts of jellyfish fisheries on ecosystems, and some of the more relevant aspects for management of these understudied fisheries. 
Table 1 Jellyfish fisheries in the Americas

\begin{tabular}{|c|c|c|c|c|c|c|}
\hline Country & Region & Status & Year(s) & Species & Gears & $\begin{array}{l}\text { Estimated } \\
\text { current annual } \\
\text { catch (tonnes) }\end{array}$ \\
\hline Argentina & $\begin{array}{l}\text { Buenos Aires } \\
\text { Province }\end{array}$ & Under investigation & 2007-present & Lychnorhiza lucerna & $\begin{array}{l}\text { Dip-net; gillnet; } \\
\text { demersal trawl }\end{array}$ & - \\
\hline Canada & British Columbia & Discontinued & 1984 & Aurelia labiata & Dip-net; seine net & - \\
\hline Canada & Newfoundland & Discontinued & 2002 & Aurelia sp. & Beam trawl & - \\
\hline Ecuador & $\begin{array}{l}\text { Guayaquil Gulf } \\
\text { Estuary }\end{array}$ & Under investigation & 2013-present & Stomolophus meleagris & $\begin{array}{l}\text { Modified gillnet; } \\
\text { tidal set-net }\end{array}$ & $48,600^{\mathrm{a}}$ \\
\hline Honduras & $\begin{array}{l}\text { Near Caratasca } \\
\text { Lagoon }\end{array}$ & Under investigation & 2007 & Stomolophus meleagris & Dip-net & - \\
\hline Honduras & Gulf of Fonseca & Under investigation & 2016 & Stomolophus meleagris & Dip-net & \\
\hline Mexico & Gulf of Mexico & Discontinued & 2000 & Stomolophus meleagris & Dip-net & - \\
\hline Mexico & Gulf of California & Expanding & 2001-present & Stomolophus meleagris & Dip-net & 15,000 \\
\hline Nicaragua & Tuapi & Expanding & 2008, 2013-present & Stomolophus meleagris & Dip-net & 1300 \\
\hline Peru & Pisco & Under investigation & 2013-present & Chrysaora plocamia & Dip-net & - \\
\hline USA & Puget Sound & Discontinued & $1960 s-1990 s$ & Aequorea victoria & Dip-net & - \\
\hline USA & Atlantic coast & Expanding & 1990s-present & Stomolophus meleagris & Shrimp trawl; seine & 4000 \\
\hline USA & Gulf of Mexico & Continuing & 1990s-present & Stomolophus meleagris & $\begin{array}{l}\text { Shrimp trawl; } \\
\text { skimmer trawl; seine }\end{array}$ & 1100 \\
\hline
\end{tabular}

${ }^{a}$ Estimate based on only 2 years of landings with exceptionally high landings in 2015

\section{Fishing for jellyfish}

When located in surface waters, jellyfish can be very abundant and caught with relatively little effort. In fact, one of the traditional concerns for jellyfish was not how to catch them, but rather how to exclude them from the catch (e.g., Broadhurst and Kennelly 1996). The design of turtle excluder devices (TEDs), which are now required in many American trawl fisheries, was adapted from devices originally devised by fishers to exclude cannonball jellyfish (Stomolophus meleagris) from shrimp trawls (Jenkins 2012). Ironically, this species of jellyfish is now the target of a growing fishery in the USA and elsewhere (see below).

A wide variety of gears are used around the globe to catch jellyfish, including dip-nets, set nets, drift nets, hand-nets, gill nets, hooks, beach seines, purse seines, weirs, and trawl nets. In some cases, combinations of gears may be used to increase the quality and size of the catch. For example, in the Ariake Sea (Kyushu, Japan) and Sarawak (Malaysia, Borneo), jellyfish may be concentrated using set nets and then collected using dip-nets (AS personal observations; Rumpet 1991). Mesh size is also an important consideration for fishers and managers, as it affects not only the abundance and quality of the catch, but also the bycatch. Minimum size limits (MSLs) are in place in some countries in order to avoid catching juvenile medusae. However, the effectiveness of MSLs in jellyfish fisheries has not been evaluated. While larger mesh sizes are likely to help minimize bycatch and avoid juvenile medusae, they can also damage larger and more valuable medusae, depending on the methods and gear being used. As such, mesh sizes should be carefully considered based on specific circumstances (also see Management below).

A wide range of vessels is used for fishing jellyfish. While diesel-powered trawlers are used in select locations (e.g., USA), most fishing is done from small (5-10 $\mathrm{m})$, powered boats operating relatively close to shore, which often carry somewhere between 1 and $5 \mathrm{t}$ of catch when fully loaded. Large catches of jellyfish on the decks or in holds of boats can result in concerns regarding vessel stability. In rough conditions, it may be especially important for vessels to have baffles in their holds in order to contain the catch and prevent it from shifting (Kingsford et al. 2000). Fishing is usually carried out during the daytime when fishers can locate medusae in surface waters. However, in some cases jellyfish may be targeted outside of daylight hours in order to avoid warm temperatures that can speed spoilage of the catch. As oceanographic 


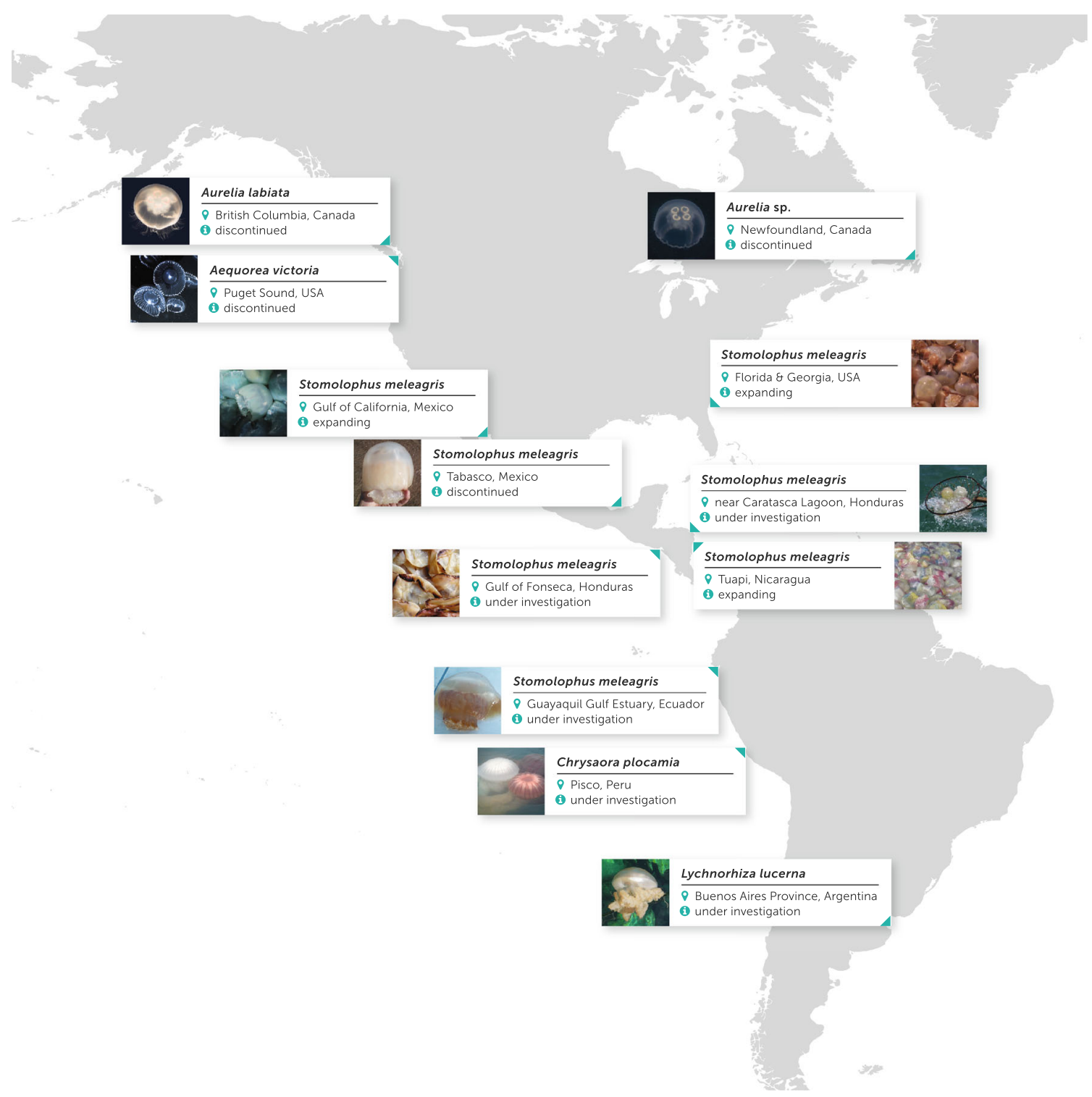

Fig. 1 Map of jellyfish fisheries in the Americas. For additional information, see Table 1

conditions such as currents, rainfall, wind, and thermal stratification influence vertical and horizontal distribution of jellyfish (Graham et al. 2001), these conditions will impact fishing activity. If jellyfish are not aggregated near the surface or visibility is not sufficient to locate them, fishers need to employ different methods and gears, which may include trawls, seines, or set nets. Each jellyfish fishery will employ gears based on a variety of factors, including access, cost, efficiency, and catchability. Kingsford et al. (2000) concluded that dip-netting is the most favorable method for catching jellyfish as it minimizes bycatch, habitat damage, catch quality, and conflict with other commercial fisheries.

\section{Target species and rhizostome diversity in the Americas}

While the FAO usually reports edible jellyfish as "Rhopilema spp.", this is incorrect in many cases. As many as 35 species of jellyfish have reportedly been 
consumed by humans (Table 2), with the majority of commercial jellyfish fisheries focusing on species from the scyphozoan Order Rhizostomeae. Although this (and many other) groups of jellyfish are polyphyletic, the taxonomy of jellyfish still requires significant revision and an updated system remains to be proposed, so the traditional nomenclature will be used here. Rhizostome jellyfish typically have tougher and more rigid tissues than other jellyfish, thereby producing the desired crunchiness that is characteristic of processed edible jellyfish. In the Americas, most established jellyfish fisheries are targeting cannonball jellyfish, usually assumed to be Stomolophus meleagris, as they are abundant in many regions and have proven to sell successfully in Asian markets. There are however, attempts to exploit other species of jellyfish in the Americas, with limited success (Table 1).

Most rhizostome jellyfish that have been studied have a polymorphic life cycle including both pelagic medusoid and sessile polypoid phases (Fig. 2). The medusoid phase typically persists for 4-8 months, but this varies depending on the species and environment in question. Indeed, the life span of some individual medusae may extend beyond a year in some cases (Arai 1997). Rhizostome medusae are dioecious and eggs may be fertilized in the water column, in the oral arms or gastrovascular cavity of the female, or even in the ovary as is the case with Cotylorhiza tuberculata (Widersten 1965; Kikinger 1992; Arai 1997; Schiariti et al. 2012a). Planulae typically form within hours of fertilization and settle upon hard substrate before metamorphosing into polyps (scyphistomae). Finding suitable habitat is likely critical for polyp recruitment. Natural habitats, such as the roots of mangrove forests, are declining in tropical regions due to coastal development (Valiela et al. 2001). Conversely, coastal development is also creating additional habitat for polyps due to a dramatic increase in artificial structures (Duarte et al. 2013). Exactly how such changes will affect edible jellyfish species remains to be seen, but developing a better understanding of polyp populations should be a priority for jellyfish fisheries researchers and managers. Polyps may asexually produce more polyps through several different modes, or may form dormant cysts under a variety of conditions (Adler and Jarms 2009; Arai 2009; Lucas et al. 2012; Schiariti et al. 2014). Ephyrae are released asexually through strobilation and subsequently join the pelagic realm, growing rapidly into medusae (Arai
1997; Palomares and Pauly 2009), after which they may be targeted by the fishery. As polyps do not necessarily perish after strobilation, and usually recover to reproduce repeatedly, this life cycle may provide a buffer against overfishing. However, jellyfish population dynamics are not well understood, and overfishing of jellyfish stocks appears possible. In fact, overfishing is likely one of the main reasons for the decline of Rhopilema esculentum catches in Chinese waters (Dong et al. 2014).

According to the literature, there are at least 13 species of rhizostome jellyfish along the American continental coastlines (Table 3) (not considering islands in the Pacific Ocean that belong to different countries). An additional 2 records are identified only to genus level (Table 3). Some species are relatively common (e.g., Cassiopea frondosa, Cassiopea xamachana, Lychnorhiza lucerna, Phyllorhiza punctata, and Stomolophus meleagris), and there is a considerable amount of literature concerning their biology and ecology (e.g., Mayer 1910; Hummelinck 1968; Calder 1973, 1982; Bolton and Graham 2004; Morandini et al. 2005; Haddad and Nogueira 2006; Schiariti et al. 2008; Rodriguez-Saenz and Segura-Puertas 2009; Carvalho-Saucedo et al. 2012; Sal Moyano et al. 2012; Schiariti et al. 2012a). Several other species have also been reported, but only once or slightly more (e.g., Cassiopea vanderhorsti, Catostylus cruciatus, Catostylus ornatellus, Catostylus tagi, Lychnorhiza arubae, and Mastigias roseus; see references in Table 3). The validity of such records and species remains uncertain given that only a few specimens are available for comparison, some misidentifications are likely, and some specimens were only seen by the author who described them. However, Appeltans et al. (2012) suggest that the number of scyphozoan species may increase after further research and more comprehensive studies. Regarding the genus Stomolophus, there may be more than the two species considered here (S. meleagris and S. fritillaria); some authors indicate morphological variation as a different variety (e.g., Morandini et al. 2005; Soares et al. 2009). Larson (1990) mentioned the dramatic color difference between the Pacific and Atlantic forms of what he considered to be S. meleagris ("prussian blue" and "milky or milky with dark chocolate pigmentation on the exumbrella" respectively). Indeed, there appears to be at least five varieties of Stomolophus cf. meleagris in the Gulf of California and Pacific Mexico 


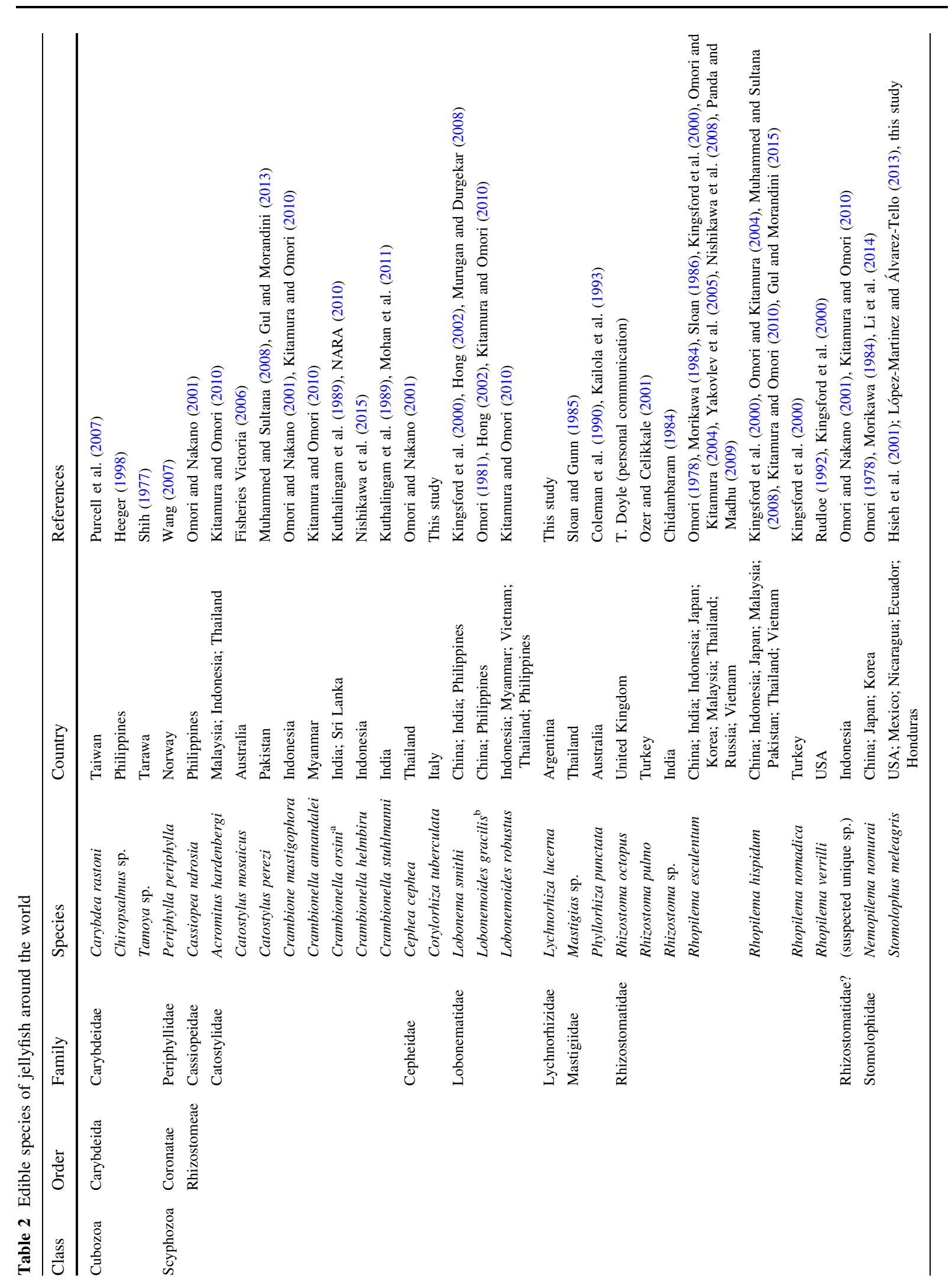




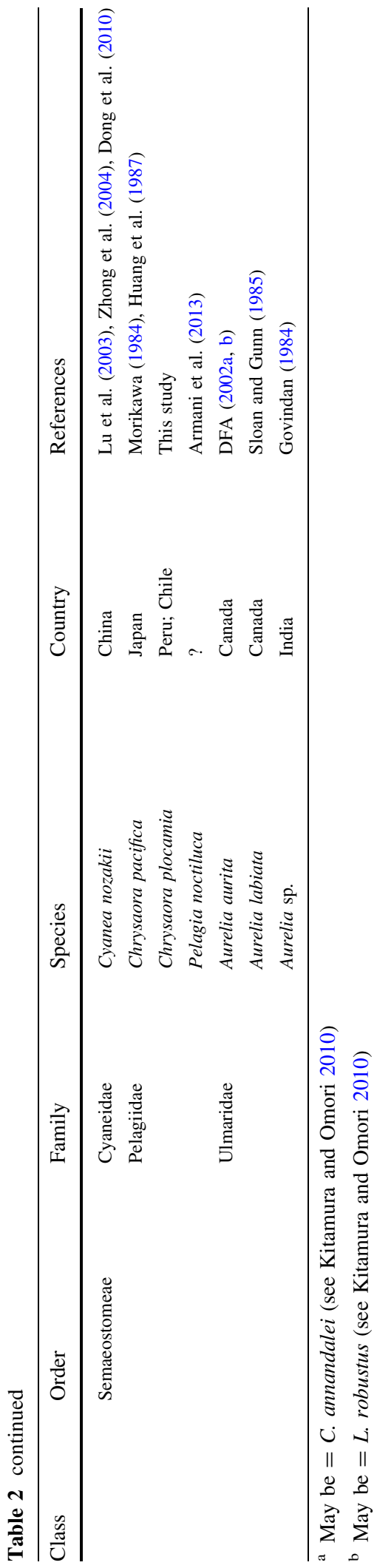

alone (JAT personal observations); however, little formal research has been conducted on the subject (but see Nevárez López 2010).

There is considerable knowledge of jellyfish diversity in certain regions of the Americas, such as the Gulf of Mexico, the east and west coasts of the USA, and the coastlines of Brazil and Argentina (Larson 1990; Mianzan and Cornelius 1999; Morandini et al. 2005; Calder 2009; Oliveira et al. in press). However, surveys for jellyfish outside of these areas are rare, and regions including the Caribbean Sea, Pacific Central America, and northern parts of South America remain understudied. Although these areas have some species listed (Mayer 1910), they are predominantly tropical waters with an expected higher diversity of rhizostomes (Kramp 1970). Moreover, simply knowing the biodiversity of rhizostome jellyfishes is not enough. In order to successfully develop jellyfish fisheries in the Americas, it is imperative that basic abundance and distribution data be collected, along with more comprehensive studies of potential areas of exploitation. Gathering and analyzing information will lead to better management practices and conservation policies.

As more coastlines of the Americas are surveyed for jellyfish, the 13-15 species of rhizostomes so far identified (Table 3) may increase. However, only five of these recognized species are known to be abundant: Cassiopea xamachana, Lychnorhiza lucerna, Phyllorhiza punctata, Rhopilema verrilli, and Stomolophus meleagris. Of these, S. meleagris is already being exploited in some regions (Fig. 1) and L. lucerna is currently being investigated in Argentina. The two remaining species ( $P$. punctata and $C$. xamachana) are not targeted at commercial scales, likely due to the fact that they are not preferred as edible species (see Table 2). As non-rhizostome jellyfish have yet to be successfully exploited at commercial scales, new opportunities for expanding jellyfish fisheries in the Americas may be limited, at least until new processing technologies are developed and market demand for semaeostome jellyfish increases.

\section{Processing jellyfish}

Most jellyfish catch is processed into a semi-dried product through a stepwise procedure of soaking in various mixtures of salts. Although rare by 


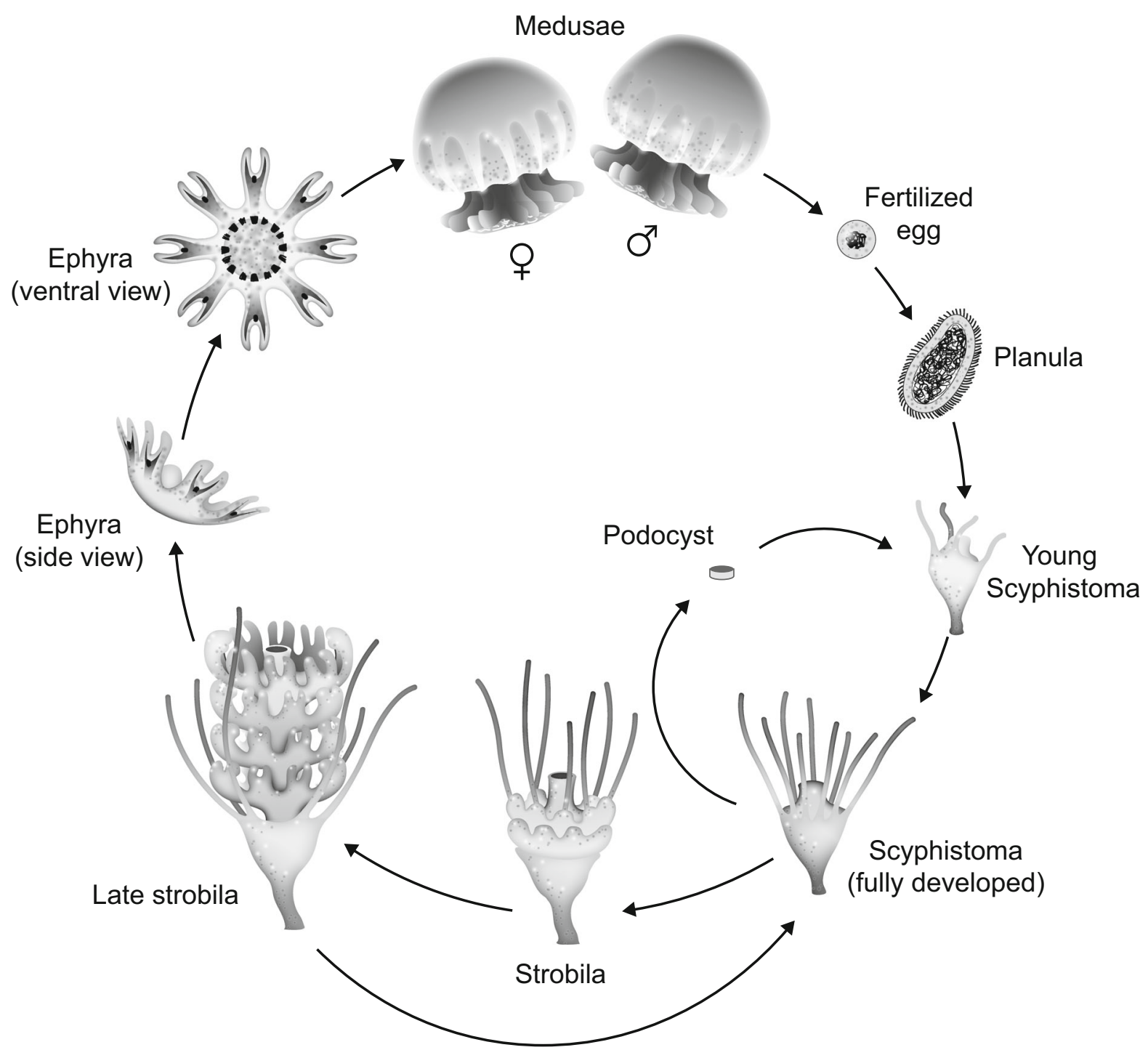

Fig. 2 Life cycle of the cannonball jellyfish Stomolophus meleagris. Gametes are released by sexually mature medusae. Fertilized eggs develop into motile, short-lived planulae larvae, which settle onto hard substrates and metamorphose into sessile

comparison, some jellyfish may be used as a fresh ingredient immediately after it is caught, as is occasionally the case with Rhopilema esculentum and Nemopilema nomurai in China (Yang and Shuang 2015). There are a number of detailed accounts on processing jellyfish written in English (e.g., Soonthonvipat 1976; Wootton et al. 1982; Chidambaram 1984; Govindan 1984; Santhana-Krishnan 1984; Sloan and Gunn 1985; Huang 1988; Suelo 1988; Rumpet 1991; Rudloe 1992; Jones and Rudloe 1995; Ozer and Celikkale 2001; Nishikawa et al. 2008), scyphistomae. Scyphistomae may increase their abundance by the asexual formation of podocysts. Young medusae (ephyrae) are produced and released into the water column by polydisc strobilation

Spanish (e.g., Álvarez-Tello 2007; Schiariti 2008; Schiariti and Mianzan 2013; Schiariti et al. 2015), and Chinese (e.g., Wu 1955; Liu 1973; Yin et al. 2000). Processing methods and techniques vary by species, market preferences, facilities, and producers. As such, here we provide only a general overview of processing techniques common to most methods.

Unlike other seafood, jellyfish are almost never frozen at sea, and are typically processed within hours of being caught in order to avoid spoilage. However, one of us (LB) recently ate reconstituted Cotylorhiza 
Table 3 Rhizostome diversity in the Americas

\begin{tabular}{|c|c|c|c|c|c|}
\hline Classification & Family & Species & Ocean & Distribution & Main records \\
\hline \multirow[t]{6}{*}{$\begin{array}{l}\text { Suborder } \\
\text { Kolpophorae }\end{array}$} & \multirow[t]{3}{*}{ Cassiopeidae } & Cassiopea frondosa & W Atlantic & Carribean, S USA & $\begin{array}{l}\text { Mayer (1910), Hummelinck } \\
\text { (1968) }\end{array}$ \\
\hline & & $\begin{array}{l}\text { Cassiopea } \\
\quad \text { vanderhorst } i^{\mathrm{a}, \mathrm{b}}\end{array}$ & W Atlantic & Curaçao & Stiasny (1922a) \\
\hline & & Cassiopea xamachana ${ }^{\mathrm{c}}$ & W Atlantic & Carribean, S USA & $\begin{array}{l}\text { Mayer (1910), Hummelinck } \\
\text { (1968) }\end{array}$ \\
\hline & \multirow[t]{3}{*}{ Mastigiidae } & Mastigias sp. ${ }^{\mathrm{a}, \mathrm{d}}$ & W Atlantic & Puerto Rico, S USA & Bayha and Graham (2011) \\
\hline & & Mastigias roseus $^{\mathrm{a}, \mathrm{b}}$ & Atlantic & Tropical Atlantic & Reynaud (1830) \\
\hline & & Phyllorhiza punctata $^{\mathrm{d}}$ & $\begin{array}{l}\text { W Atlantic; NE } \\
\text { Pacific }\end{array}$ & $\begin{array}{l}\text { SW + SE U.S.A; Puerto } \\
\text { Rico; Brazil }\end{array}$ & $\begin{array}{l}\text { Moreira (1961), Garcia (1990), } \\
\text { Larson and Arneson (1990), } \\
\text { Silveira and Cornelius } \\
\text { (2000), Bolton and Graham } \\
\text { (2004) }\end{array}$ \\
\hline \multirow[t]{6}{*}{$\begin{array}{l}\text { Suborder } \\
\text { Daktyliophorae }\end{array}$} & \multirow[t]{3}{*}{ Catostylidae } & Catostylus cruciatus $^{\mathrm{a}, \mathrm{e}}$ & SW Atlantic & S Brazil & $\begin{array}{l}\text { Lesson (1830), Morandini } \\
\text { (2009) }\end{array}$ \\
\hline & & Catostylus ornatellus $^{\mathrm{a}}$ & SE Pacific & Ecuador & Vanhöffen (1888) \\
\hline & & Catostylus tagi ${ }^{\mathrm{a}, \mathrm{d}}$ & E Pacific & W Panama & Stiasny (1922b) \\
\hline & \multirow[t]{3}{*}{ Lychnorhizidae } & Lychnorhiza arubae ${ }^{\mathrm{a}}$ & W Atlantic & Aruba & Stiasny (1920) \\
\hline & & Lychnorhiza lucerna & SW Atlantic & Colombia to Argentina & $\begin{array}{l}\text { Mayer (1910), Silveira and } \\
\text { Cornelius (2000) }\end{array}$ \\
\hline & & Lychnorhiza sp. & $\begin{array}{l}\text { NE Pacific; W } \\
\text { Atlantic }\end{array}$ & Mexico; Colombia & $\begin{array}{l}\text { Larson (1990), Cedeño-Posso } \\
\text { and Lecompte Pérez (2013) }\end{array}$ \\
\hline \multirow{3}{*}{$\begin{array}{l}\text { Superfamily } \\
\text { Rhizostomatoidea }\end{array}$} & Rhizostomatidae & Rhopilema verrilli & NW Atlantic & $\mathrm{S}+\mathrm{E}$ USA & Calder (2009) \\
\hline & \multirow[t]{2}{*}{ Stomolophidae } & Stomolophus fritillaria ${ }^{\mathrm{a}}$ & SW Atlantic & $\begin{array}{l}\text { Venezuela to French } \\
\text { Guyana }\end{array}$ & Haeckel (1880), Ranson (1949) \\
\hline & & Stomolophus meleagris & $\begin{array}{l}\text { W Atlantic; E } \\
\text { Pacific }\end{array}$ & $\begin{array}{l}\text { SE USA to Brazil; SW } \\
\text { USA to Ecuador }\end{array}$ & Mayer (1910), Calder (2009) \\
\hline
\end{tabular}

${ }^{a}$ Found only once or a few times

b Species validity in question

c $?=$ C. andromeda, non-indigenous (see Holland et al. 2004)

$\mathrm{d}$ Reported as non-indigenous

e ? = Lychnorhiza lucerna (see Mianzan and Cornelius 1999)

tuberculata that had been frozen at ultra-low temperature (close to $-80{ }^{\circ} \mathrm{C}$ ), and the quality and taste of the product was excellent, suggesting that freezing of some jellyfish species may be possible as an alternative to traditional chemical processing. Storage onboard fishing vessels sometimes includes chilled seawater slurries to delay degradation. Processing facilities range from small beachside tents to industrial factories. Processing sometimes begins onboard the fishing vessel, and is often carried out thereafter by the fishers, their families, or fishing cooperatives near the fishing grounds.

Separation stage

All rhizostome jellyfish lack tentacles, and instead have prominent oral arms (sometimes called 'legs' or incorrectly referred to as 'tentacles'). While both the oral arms and the bell are edible, they are typically separated during the initial stages and processed separately. Occasionally, especially with very large specimens (e.g., Rhopilema hispidum, R. esculentum), the oral arms are separated into the individual arms and the manubrium, often referred to as the 'stem'.

\section{Cleaning stage}

Whole or separated jellyfish are generally washed with high-volume, low-pressure seawater to remove the mucus, membranes, and gonads, as well as sand and possibly bacteria. The bells may also be scraped (sometimes with bamboo tools) to expedite the cleaning process and remove the surface "skin" if there are denticulations, or washed in industrial 
stirring machines. Initial washing steps are important to facilitate the penetration of the processing salts into the tissues, allowing osmosis and dehydration to proceed at a faster rate and thereby minimizing spoilage.

\section{Salting/curing stages}

Jellyfish are soaked in varying amounts of salt $(\mathrm{NaCl})$ and alum (e.g., $\mathrm{KAl}\left[\mathrm{SO}_{4}\right]_{2} \cdot 12 \mathrm{H}_{2} 0$ ). Soaking in various mixtures reduces the water content of the jellyfish and transforms the gelatinous tissues into the distinctive crispy and firm texture that is the most desirable characteristic of edible jellyfish. Salt is essential to reduce the water content of the tissues through osmosis, and alum is required to reduce the $\mathrm{pH}$ and precipitate the proteins to achieve the unique elastic yet crispy texture. The lowered $\mathrm{pH}$ greatly reduces the chances of microbial growth, thereby extending the shelf life of the final product. Using only salt or alum alone may not result in a satisfactory product (Wootton et al. 1982). In some regions, such as Malaysia, Thailand, and the Philippines, a small amount of soda $(\mathrm{NaOH})$ may be added to the salt-alum mix to facilitate additional dehydration. Depending on the market preferences and the variety of jellyfish being used, bleaching agents containing hydrogen peroxide may be added to whiten the product, as is the case for Stomolophus meleagris from Mexico bound for China. The quality of the salt used can also have a significant impact on processing, with higher-quality fine salt penetrating the tissues faster, while coarser rock salt will dissolve slower but last longer.

Jellyfish are typically soaked in several different salt-alum mixtures for specified times. The duration of the entire process varies greatly depending on the species and processing formulas, and may last anywhere from 4 to 40 days. Shorter processing times have been developed in the USA, facilitated by automation, industrialization, and the fact that medusae of Stomolophus spp. are typically smaller than other species of edible jellyfish. Even minor differences in the amounts of salt and alum used, or in the number and duration of salting stages, can represent important differences in the final product quality. Jellyfish processing is by no means an exact science, but instead is considered an art and is often conducted behind closed doors by so-called 'Jellyfish Masters' using closely guarded recipes (Rudloe 1992; Jones and
Rudloe 1995). In areas where jellyfish products are to be exported, processors typically receive instructions from their buyers, as different markets prefer different tastes, colors, and textures of products. The weight of semi-dried processed jellyfish is usually $15-20 \%$ of the original wet weight, but may range from $7 \%$ to more than $25 \%$, depending on the species and processing method used.

There are a number of concerns about the effluent that is created from processing facilities. Primarily, these concerns surround the disposal of huge amounts of slime-salt wastewater created during the initial processing stages. This issue has been the subject of recent debate in South Carolina, USA, as companies are looking to expand production but are being met with resistance and regulation. Currently, Raffield Fisheries in Florida, USA is dealing with the problem by first reducing the amount of organic matter in the wastewater with aeration and agitation, followed by quantity dilution to an acceptable extent before discharging the wastewater into the sea. The disposal of large quantities of processing wastewater from multiple processing sites is a concern, and this issue would need to be resolved in highly regulated areas, such as the coastal USA, before high-volume shoreside processing can proliferate. In most countries, the effluent from processing facilities is not regulated. Research into the development of improved processing techniques that minimize the harmfulness and toxicity of effluent should be a priority, and potential solutions may have the added benefits of reducing costs, minimizing the negative health effects associated with processing chemicals, such as aluminum (see below), as well as the utilization of new species and markets.

\section{The edible product}

Jellyfish may be served on their own or as ingredients in salads, soups, and other dishes. In preparation for consumption, semi-dried, salt-preserved jellyfish products are typically desalted and partially rehydrated by soaking in water for several hours or overnight, often with numerous water changes. Fresh and desalted jellyfish products have little flavor, and are usually served with sauces that can include sesame oil, soy sauce, vinegar, and sugar. Jellyfish may also be an ingredient of more elaborate dishes. Preparation 
varies depending on the product and region, but jellyfish are often shredded and scalded with hot water prior to serving. More recently, ready-to-use (RTU) jellyfish products have become increasingly popular, as they do not require soaking, and are usually served with sauces as a ready-to-eat snack. Prices for jellyfish vary widely depending on the product, but processed jellyfish may typically be found at market fetching 2-10 USD/kg.

Rehydrated (i.e., desalted) edible jellyfish are typically $\sim 92$ to $96 \%$ water and $\sim 3$ to $7 \%$ protein, depending on the species, the type of product, and the processing methods used. Levels of carbohydrate, fat, and cholesterol are nearly undetectable in a single serving. With approximately 36 food calories per $100 \mathrm{~g}$ (USDA 2015), edible jellyfish have been declared as a natural diet food, comparable to vegetables such as broccoli and carrots, and only double the energy density of cucumber and celery. Macro elements including calcium, magnesium, potassium, and sodium are high in fresh jellyfish tissues as their contents are affected by seawater; however, these elements are substantially reduced in edible jellyfish after desalting. While most salts can be removed by soaking in water, processed jellyfish contain elevated levels of aluminum due to the alum curing agent (Ogimoto et al. 2012; Zhang et al. 2016). The aluminum binds to the proteins in the gelatinous tissue, resulting in the desired crunchy and crispy texture. As oral arms are typically higher in protein, they may contain several times the aluminum level of the bell. As solid salt and alum are usually packaged with the processed jellyfish to preserve the product during shipping and storage, longer exposure to the curing agent increases the salt penetration and tissuebinding of the aluminum, resulting in a higher Alcontent. Cannonball jellyfish (S. meleagris) typically have relatively lower Al-content due to the shorter processing times compared with jellyfish processed in Asia. As there are negative health effects associated with the consumption of aluminum, including neurobehavioral toxicity (Perl and Brody 1980; Nayak 2002), the development of processing techniques that avoid the use of alum is desirable (Hsieh and Rudloe 1994). Unfortunately, current efforts to develop new processing technologies appear to be limited.

In contrast with the negative effects of aluminum consumption, there are numerous purported health benefits to consuming jellyfish. Traditional Chinese
Medicine (TCM), as well as advertisements in magazines and non-scientific publications, claim that eating jellyfish is beneficial for treating arthritis, high blood pressure, bronchitis, cancer, ulcers, fatigue, swelling, burns, as well as softening skin and aiding weight loss. Scientific studies evaluating such claims are rare to nonexistent. However, recently cannonball jellyfish collagen was found to exhibit both preventative and therapeutic effects on antigen-induced arthritis in laboratory animals. The results showed that rats fed with low doses of jellyfish collagen had significantly reduced incidence, onset, and severity of antigen-induced arthritis (Hsieh 2005). No human clinical data are available.

Some individuals may also experience negative reactions soon after consuming processed jellyfish, such as anaphylaxis; however, such cases appear to be extremely rare (Imamura et al. 2013; Inomata et al. 2014). Mild allergic reactions to the consumption of jellyfish have been observed, such as swelling of the mouth, but also appear to be rare (JAT personal observations). There is a solitary case of ciguatera poisoning suspected to be caused by consumption of jellyfish from American Samoa, although the details are vague (Zlotnick et al. 1995).

In general, processed edible jellyfish has a surprising crunchy and crispy texture. The value of the product is often determined based on a combination of textural factors including crunchiness, elasticity, and tenderness. The product's color can also be important, with freshly processed jellyfish having a creamy white color, which will gradually turn to yellow and then brown as the product ages. Depending on the species, edible jellyfish may also have hues of blue and red. As mentioned, some products bound for China may be bleached white during processing.

Information about the shelf life of cured jellyfish varies. Huang (1988) noted that product from $S$. meleagris can be stored for at least 6 months at $10{ }^{\circ} \mathrm{C}$. Hsieh et al. (2001) stated that edible jellyfish products last up to a year at room temperature, which can be extended to more than 2 years if kept cool. Freezing of processed jellyfish for storage is possible for short stages (Govindan 1984; Santhana-Krishnan 1984; Kingsford et al. 2000; Ozer and Celikkale 2001); although frozen jellyfish will begin to dry out and form wrinkles, negatively affecting the appearance and texture of the product, and is therefore not recommended for prolonged periods (Huang 1986; Rudloe 
1992; Subasinghe 1992; Hsieh et al. 2001). As mentioned, freezing at ultra-low temperatures may provide alternatives to chemical processing and potential longer-term storage.

\section{Other uses of jellyfish}

Jellyfish may be targeted for a number of reasons other than as food for humans. In some cases, jellyfish have been fished simply to remove them from locations where they are a nuisance to tourism or other industries. Such efforts have proven effective in Hawaii (Hofmann and Hadfield 2002; Kelsey 2009); however, these cases involved Cassiopea spp., which are relatively sedentary (Holland et al. 2004). Cannonball jellyfish (Stomolophus meleagris) have also been removed in the past from canals in Florida, where they clogged the intake pipes of a nuclear power plant (Jones and Rudloe 1995). Fishers have also been paid to remove Cotylorhiza tuberculata in Mar Menor in the Mediterranean Sea, a species which ironically appears to have increased largely due to anthropogenic impacts (Brotz and Pauly 2012). While it appears that fishing of medusae may have helped to reduce the jellyfish population there, it was an extremely expensive program, and environmental conditions are likely much more influential of the population dynamics in question (Prieto et al. 2010; Ruiz et al. 2012).

Jellyfish have been used successfully as partial feedstock for a variety of animals, including farmed chickens and pigs (Hsieh and Rudloe 1994; CIESM 2010). There is also increasing interest in using jellyfish as feed in aquaculture (e.g., Gopakumar et al. 2008; Miyajima et al. 2011a, b; Wakabayashi et al. 2012). Jellyfish may be used as bait, such as in Japan where parts of the giant jellyfish Nemopilema nomurai are used for sea bream fishing (Omori and Kitamura 2004). The practice of using jellyfish as bait in fish traps in India extends back decades, and probably longer (Prabhu 1954; Thomas 1969; Varghese et al. 2008). Artisanal fishers in Peru have used gonads from Chrysaora plocamia as bait for targeting Seriolella violacea, commonly known as cojinova or palm ruff (Mianzan et al. 2014). Historically, fishers in Peru also used large blooms of $C$. plocamia to locate leatherback sea turtles (Dermochelys coriacea), which were hunted for their meat, especially during the 1960s, 1970s, and 1980s.
Jellyfish have also been central to a range of advances in medical research. These have included several investigations of jellyfish constituents and toxins, some of which have important biomedical and pharmacological properties (e.g., Ovchinnikova et al. 2006; Yu et al. 2006; Masuda et al. 2007; Ohta et al. 2009; Balamurugan et al. 2010; Mariottini and Pane 2010; Zhuang et al. 2010; Morishige et al. 2011; Zhuang et al. 2012a, b; Kawabata et al. 2013; Leone et al. 2015). Research on some groups of jellyfish has led to a better understanding of ocular evolution (Nilsson et al. 2005), as well as two Nobel Prizes: one in 1913 for the discovery of anaphylaxis, and another in 2008 for the discovery and development of green fluorescent protein (GFP). Jellyfish have also informed the field of design engineering (e.g., Dabiri 2011; Najem et al. 2012; Ristroph and Childress 2014), where their biomechanics are often mimicked due to their simple and efficient design (Gemmell et al. 2013). Most of the above applications do not require the removal of jellyfish from the wild at commercial scales. One exception is the processing of jellyfish to extract collagen, which may be used in a variety of applications including cosmetics and pharmaceuticals (Addad et al. 2011). One company based in France (www.javenech.com, accessed 26 June 2015) processes several tonnes of Rhizostoma pulmo caught in the Atlantic Ocean for collagen each year. Research into extracting collagen from other species is ongoing, including Lychnorhiza lucerna in SE Brazil.

Although the processes involved are new and still developing, jellyfish are being used or proposed for use in a number of industrial applications. In Russia, jellyfish have been successfully added to cement, which ultimately increased the mechanical strength of traditional cement by $50 \%$ (CIESM 2010), although unfortunately the details are vague. Experiments have also demonstrated that jellyfish can successfully be used as fertilizer for a variety of plants, trees, and crops (e.g., Fukushi et al. 2004, 2005; Chun et al. 2011; Kim et al. 2012; Hossain et al. 2013; Hussein and Saleh 2014; Seo et al. 2014; Hussein et al. 2015). There are even recent reports that a company in Israel has developed an absorbent and biodegradable material from jellyfish that could be used in products such as diapers and paper towels (Shamah 2014).

Most of the technologies that propose to use jellyfish in medical and industrial applications are in their infancy, and thus it will likely be sometime 
before there is significant demand for jellyfish other than for food. Additional applications, such as the use of jellyfish as biomonitors of pollution in the marine environment (e.g., Templeman and Kingsford 2010; Morabito et al. 2014) would likely not require significant numbers of medusae. Nonetheless, it is conceivable that jellyfish could be used in a variety of future applications, a strategy that has been proposed to deal with the increasing problems associated with jellyfish blooms (e.g., Purcell et al. 2007; Richardson et al. 2009; Purcell 2012).

\section{Ecological impacts of fishing for jellyfish}

All fisheries affect the environment, but understanding the impacts to food webs and habitats is a challenge. Some impacts are measurable, including habitat damage and bycatch. Habitat damage is mostly a concern with gears such as bottom-trawls and traps, neither of which are typically used for jellyfish fisheries. The most common fishing method employed by jellyfish fisheries is dip-netting, which results in relatively low levels of bycatch and virtually no habitat damage. However, numerous species of juvenile fishes have been documented to associate with jellyfish, presumably using the medusae as food and/or refugia from predators (e.g., Jones 1960; Arai 1988; Kingsford 1993; Brodeur 1998; Purcell and Arai 2001; López-Martínez and Rodríguez-Romero 2008; Mianzan et al. 2014). In addition, many invertebrates are known to associate with jellyfish, potentially benefitting from habitat, food, refugia, and transportation (e.g., Brandon and Cutress 1985; Arai 2005; Browne and Kingsford 2005; Towanda and Thuesen 2006; Sal Moyano et al. 2012; Schiariti et al. 2012b; ÁlvarezTello et al. 2013; Fleming et al. 2014). As such, bycatch concerns from jellyfish fisheries cannot be eliminated entirely, and will likely increase with seine or trawl gears (Panda and Madhu 2009).

Bycatch in the trawl fishery for cannonball jellyfish Stomolophus meleagris was examined in detail in Georgia, USA. In total, 133 tows were examined between 2005 and 2012. The results, presented by Page (2015), show that 38 species of fish, as well as 3 species of invertebrates (not including spider crabs Libinia spp., which are symbiotic with S. meleagris) were recorded as bycatch. The most commonly observed bycatch were harvestfish Peprilus paru
(41\%), cownose ray Rhinoptera bonasus (11\%), Atlantic bumper Chloroscombrus chrysurus (11\%), butterfish Peprilus triacanthus (11\%), and blue crab Callinectes sapidus (7\%). The 3 finfish species (harvestfish, Atlantic bumber, and butterfish) are all known to associate with jellyfish, presumably using them as refugia from predators, and potentially becoming ectoparasites that feed directly on the medusae (Purcell and Arai 2001). As such, it is not surprising that these species form a major component of the bycatch (Page 2015). A similar associative relationship also explains the vast quantities of spider crabs that were caught as bycatch. Other species that are know to associate with $S$. meleagris medusae but were absent as bycatch may be due to the seasonality of the fishery and/or the ability of species to escape the nets (e.g., carangids). Given that the top 5 bycatch species (excluding spider crabs) comprised approximately $80 \%$ of all individuals caught, it can be said that "the commercial cannonball jellyfish trawl fishery in Georgia is dominated by a few recurring species and is minimal relative to the bycatch associated with another important trawl fishery in the state-namely the commercial food shrimp trawl fishery" (Page 2015). Indeed, $24 \%$ of the tows analyzed contained zero bycatch (excluding spider crabs). Nonetheless, those species comprising the majority of the bycatch can be caught in significant quantities, and may be of commercial and/or ecological concern.

Other species caught as bycatch may also be of concern, even if they are less abundant, such as sea turtles. As mentioned, jellyfish were so bothersome to shrimp fishers in the past that modifications were made to trawl gear that facilitated the exclusion of jellyfish while still permitting shrimp to travel into the codend (Jones and Rudloe 1995). Essentially, a series of metal bars is used to divert anything larger than the space between the bars to an escape hatch, whereas anything smaller passes through the codend. These device modifications dramatically reduced the catch of jellyfish, often by more than $80 \%$ (Huang et al. 1987), but also proved to successfully exclude sea turtles, and ultimately became known as turtle excluder devices or 'TEDs' (Jenkins 2012). TEDs are now mandatory in the state waters of Georgia, but since they are so effective at excluding jellyfish, most jellyfish fishers there opt to trawl in the adjacent federal waters where TEDs are not required (Page 2015). During the aforementioned bycatch study, a total of 13 protected 
species (11 sea turtles and 2 common bottlenose dolphins) were caught during the 133 observed tows (which represented $<5 \%$ of all tows during the period). While some animals caught as bycatch are released alive, tows routinely exceed $1 \mathrm{~h}$ in duration (average of $0.55 \mathrm{~h}$ ), suggesting that mortality of airbreathing species could be significant. There are ongoing efforts to design TEDs with spacing between the bars that is sufficient for jellyfish to pass through, but not turtles (Page 2015).

Although jellyfish were often perceived to be trophic dead-ends (e.g., Verity and Smetacek 1996; Sommer et al. 2002), this perception is changing. Many sea turtles will prey on jellyfish during some stage of their lives, and the leatherback sea turtle Dermochelys coriacea is an obligate jellyfish predator, with individuals potentially eating hundreds of kilograms of jellyfish in a single day (Duron-Dufrenne 1987; Heaslip et al. 2012). As the leatherback turtle is critically endangered, fishing for jellyfish in waters deemed critical habitat could be subject to restrictions in some jurisdictions. Recent investigations are also revealing the importance of jellyfish as prey for more than one hundred species of fish (Arai 1988; Ates 1988; Mianzan et al. 2001; Purcell and Arai 2001; Arai 2005; Pauly et al. 2009; Cardona et al. 2012). In addition, large blooms of jellyfish that die and sink to the ocean floor (known as 'jelly-falls') have mainly been investigated for their role in the biological pump (Lebrato et al. 2012, 2013); however, it is becoming apparent that they may also be an important nutritional input for benthic animals (e.g., Henschke et al. 2013; Sweetman et al. 2014).

Jellyfish can also be voracious predators and often have very significant impacts on the abundance, biomass, and size composition of zooplankton at lower trophic levels (Möller 1980; Mills 1995; Purcell and Arai 2001). In some cases, there is convincing evidence that overfishing of small pelagic fish has resulted in an alternate ecosystem state whereby jellyfish are released from competition and come to dominate, such as the Benguela Current ecosystem (Bakun and Weeks 2006; Lynam et al. 2006; UtnePalm et al. 2010; Flynn et al. 2012; Roux et al. 2013). Thus, one could posit that the reverse would be true, i.e., that overfishing of jellyfish in such an ecosystem may facilitate the recovery of fish at similar trophic levels. However, in reality, such situations may not be straight-forward or predictable (Gibbons et al. 2016).
Nonetheless, the extensive removal of medusae may help to mitigate some of the detrimental impacts of jellyfish on human industry (Purcell et al. 2007; Lucas et al. 2014). Therefore, the removal of jellyfish may be perceived as beneficial or detrimental depending on the food web dynamics, management goals, and species in question.

Beyond their extensive roles in food webs, jellyfish also provide a number of ecosystem services such as carbon transport, nutrient liberation, and oceanic mixing (Doyle et al. 2014). Given all of their influential roles in ecosystems, removing jellyfish in large quantities is likely to have significant consequences. Unfortunately, jellyfish have been understudied and are typically ignored or simplified in ecosystem models (Pauly et al. 2009). As such, the impacts of removing large amounts of jellyfish through fishing are not well understood (Gibbons et al. 2016).

\section{Jellyfish fisheries in the Americas}

\section{Argentina}

For a number of years, jellyfish have been caught around the Río de la Plata along the northern coast of Buenos Aires province (Schiariti 2008). These jellyfish are being processed by scientists and fisheries researchers in order to investigate the quality of the product produced from Lychnorhiza lucerna-a rhizostome jellyfish that has previously not been reported as being consumed (Schiariti and Mianzan 2013). $L$. lucerna interferes with tourism as well as fisheries for finfish and shrimp (Schiariti 2008; Nagata et al. 2009), so there is interest in targeting this species. Moreover, developing an alternative resource for fishers in the area would be welcome, as declining catches of more traditional fisheries resources have created economic hardship for many in the region. Given that the peak season for finfish is in the austral winter, and medusae appear during the summer, a targeted jellyfish fishery could help to compensate for the low fishing activity characteristic of the summer season. This species also occurs in the neighboring waters of southern Brazil and Uruguay as evidenced by bycatch records and scientific studies (Schiariti 2008; Nagata et al. 2009; Schroeder et al. 2014), suggesting the area of potential exploitation for this species is considerable. 
Several trials have been conducted in order to produce sample products. When fishing occurs, 15-20 small boats up to $15 \mathrm{~m}$ in length will use a variety of gears (depending on the size of the vessel) including demersal trawls, gill nets, and dip-nets. The gears and boats fishing for jellyfish also depend on meteorological conditions, as winds and currents can strongly affect the locations of L. lucerna blooms between canals and further offshore. Bycatch is also a concern, as the jellyfish season coincides with the reproductive timing of several commercially important finfish species. Further investigation and refinement of gears and techniques is expected to help minimize bycatch. To date, processing of jellyfish has been performed by fisheries researchers under instruction from potential buyers, and initial responses from Chinese and Malaysian importers has been positive. However, a major hurdle to the establishment of a permanent jellyfish fishery in Argentina is uncertainty regarding how much jellyfish can be produced from the region on a consistent basis, as buyers necessitate a minimum to be involved. Significant investment is required to undertake proper biomass assessments, investigate the costs involved, and acquire a better understanding of jellyfish population dynamics in the region. Policymakers in the area continue to perceive a potential jellyfish fishery with incredulity, and are dismissive about jellyfish providing significant economic value. Fishers in the region are less dismissive, as they are highly economically motivated and have been working directly with fisheries researchers and potential buyers for several years. Until the economic and ecological knowledge gaps can be filled, a fishery for jellyfish in Argentina remains undeveloped.

\section{Canada}

Canada has explored fisheries for jellyfish on the Atlantic and Pacific coasts. However, both test fisheries did not continue, predominantly due to the fact that they targeted Aurelia spp., for which there is limited demand.

Fisheries and Oceans Canada (also known as the Department of Fisheries and Oceans, or DFO) explored the possibility of a fishery for Aurelia labiata in coastal British Columbia in 1984. Sloan and Gunn (1985) present details for 11 dip-net and two seine fishing cruises conducted between August and November in the northern Strait of Georgia. The total catch was $2.82 \mathrm{t}$, which was then processed using three different protocols from potential Japanese buyers. Samples were provided to Chinese fish wholesalers and to Japanese and Chinese restaurateurs in Vancouver. The product was deemed unsuitable, based mainly on the poor texture that lacked the preferred crunch. Ultimately, the test fishery for jellyfish in British Columbia did not continue.

The test fishery on Canada's east coast was implemented to understand the methods and costs involved in producing jellyfish, and to evaluate the potential market (DFA 2002a). In addition, jellyfish frequently interfere with active and passive fishing gears in the region, making a targeted fishery even more desirable (DFA 2002b). An estimated $49 \mathrm{t}$ of jellyfish were caught over a period of 2 weeks in September 2002 in Newfoundland's Trinity Bay; however, only about $1 \mathrm{t}$ was retained, with the rest being discarded at sea (DFA 2002b). A 50-foot shrimp beam trawl was used, towed at approximately 1 knot. Catches consisted of approximately $90 \%$ Aurelia sp. and $10 \%$ Cyanea capillata, with the latter reportedly being too delicate to handle. The subsample of Aurelia retained for processing was stored onboard the ship in an insulated container containing a slurry of slush ice and $1 \%$ alum. Approximately $1.1 \mathrm{t}$ of jellyfish were processed and samples were sent to China, Taiwan, and Florida, USA for market testing (DFA 2002b). Due to a lack of demand for semaeostome jellyfish, as well as unrefined handling and processing techniques, the test fishery was discontinued.

\section{Ecuador}

In 2013, Chinese dealers began promoting the possibility of catching jellyfish (presumably Stomolophus meleagris) from Ecuadorian waters. Shellfish fishers, who have been struggling to generate sufficient income, welcomed the proposal. Approximately 100 small $(\sim 10 \mathrm{~m})$ fiberglass and wooden boats began fishing for jellyfish using modified gillnets and set-nets within and around the Guayaquil Gulf Estuary (Fig. 3). In 2014, an astounding 78,000 t of jellyfish were landed (most of which was caught in February and March), processed, and exported to China, Japan, and Thailand. While studies are currently underway to evaluate the impacts of the fishery and to establish management regulations, the fishery was completely closed from May to September 2014 as processing facilities were 

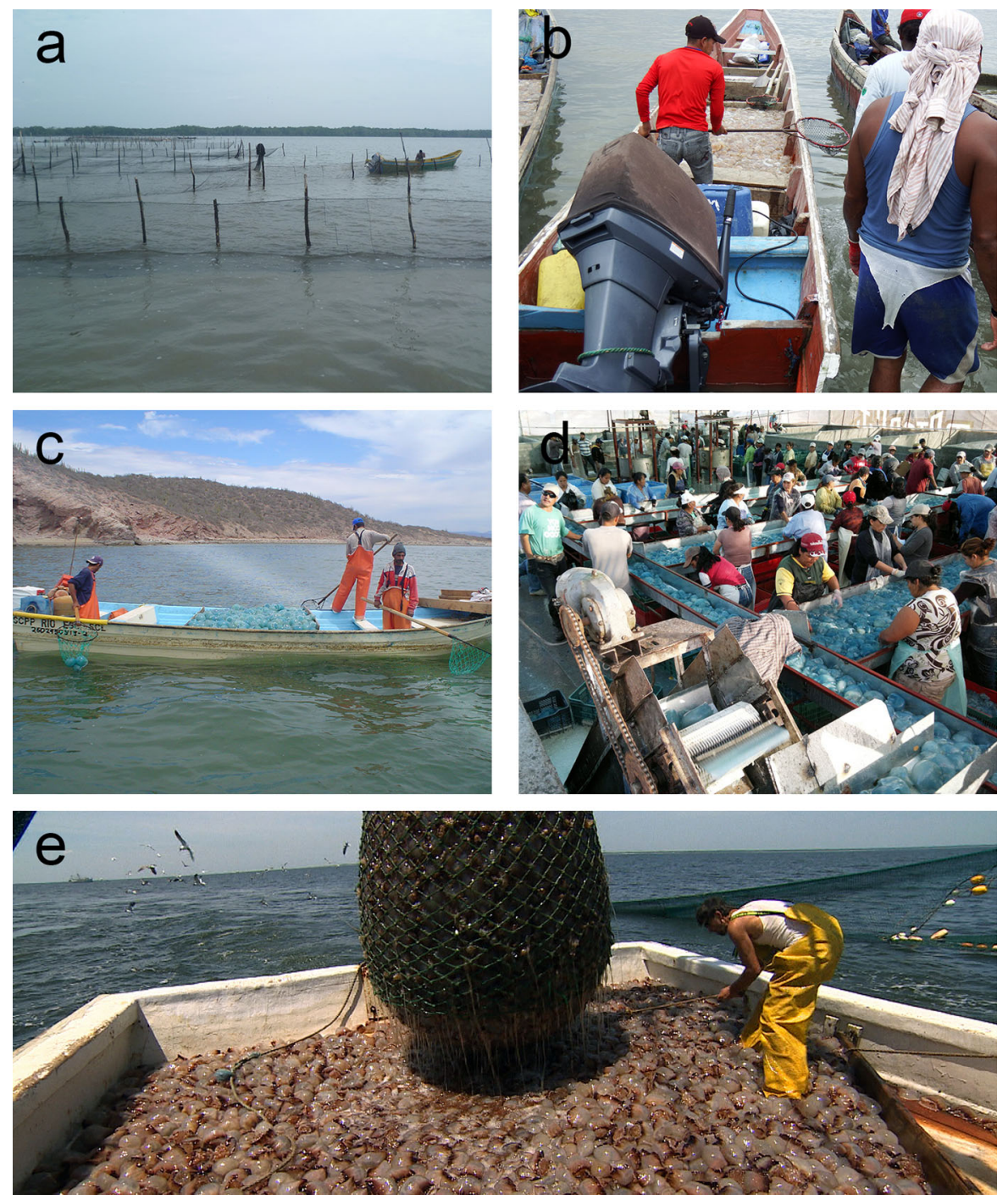

Fig. 3 Photographs from active jellyfish fisheries in the Americas. a fishers deploy set nets in Ecuador, photo by Richard Panchana, b fishers prepare to unload their catch in Ecuador, photo by Evelyn Ramos, $\mathbf{c}$ fishers catch jellyfish in

shuttered due to a lack of environmental oversight. Catching and processing of jellyfish in Ecuador continued in 2015, but to a lesser degree, with landings of 9135 t. Given the environmental concerns and the supply of jellyfish from nearby in Mexico, the ultimate scale of Ecuador's jellyfish fishery remains unclear.

Honduras

In 2007, samples of a species of Stomolophus (likely $S$. meleagris) were caught along the Atlantic coast of
Mexico's Gulf of California, photo by Javier Álvarez-Tello, d processing of jellyfish in Mexico, photo by Javier ÁlvarezTello, e trawling for jellyfish in Georgia, USA, photo courtesy Canadian Broadcasting Corporation

Honduras (around the Caratasca Lagoon) using small boats with dip-nets to test for exploitation potential. A small processing facility administered by Chinese dealers has apparently existed there for almost 10 years, but recently ceased operation due to a number of logistical issues. Medusae from the Atlantic coast of Honduras also have a ring around their bell margin, which is generally not favored in Asian markets. A newer facility was built in 2013 (Herrera 2015), a year when FAO reported a catch of $50 \mathrm{t}$ of jellyfish for Honduras. In 2015, a cooperation 
agreement was signed between the government, an organization representing aboriginal fishers, and a seafood processing company to further investigate the possibility of developing the jellyfish fishery in Honduras, this time in the Gulf of Fonseca in Pacific waters.

\section{Mexico}

Mexico began fishing for cannonball jellyfish (Stomolophus meleagris) in 2000 in the Gulf of Mexico off the state of Tabasco. However, the fishery moved to the Gulf of California in 2001, primarily to the shallow coastal waters along the state of Sonora. A summary of the fishery is provided by López-Martinez and Álvarez-Tello (2013). Average annual catches are $10,000-15,000 \mathrm{t}$, but may vary from $1000 \mathrm{t}$ to a peak of more than $30,000 \mathrm{t}$ in 2015 . The fishery started relatively small, with about 70 small boats ('pangas'), each with a crew of two or three fishers dip-netting for jellyfish (Fig. 3). In 2010, management measures were approved that would set a minimum size limit (MSL), restrict gears, and limit fishing effort, among others. However, the scale of the fishery continued to escalate, partially due to a lack of enforcement, and in 2013, over 1000 pangas fished for jellyfish, with the season lasting only 5 days. While catches have remained relatively large, variable fishing seasons and access to the fishery continue to be concerns for those involved. It remains to be seen what additional management and enforcement measures become implemented in Mexico; however, continued research and the development of new processing technologies provide some optimism.

\section{Nicaragua}

In 2008, 205 t of jellyfish (a species of Stomolophus, most likely $S$. meleagris) were caught and processed in Tuapi, near the city of Puerto Cabezas on Nicaragua's Atlantic coast. There were approximately 34 small wooden and fiberglass boats involved in the fishery, with a typical capacity of about $1.5 \mathrm{t}$ each. Fishermen used dip-nets with a 2-inch mesh size. Bells and oral arms were processed separately, yielding $57 \mathrm{t}$ of processed jellyfish that was exported to Asia. The fishery did not continue in subsequent years, potentially due to a combination of inferior product quality and regulatory obstacles imposed by local authorities. However, interest in catching jellyfish in Nicaraguan waters was recently renewed, and an estimated 659 and $1953 \mathrm{t}$ of jellyfish were caught in 2013 and 2014 respectively.

\section{Peru}

There have been recent attempts to exploit Chrysaora plocamia along the coasts of Peru, particularly near Pisco, for export to China. While there have been stakeholder meetings and commissioned reports, the fishery has not developed, mainly due to the fact that the target species is a semaeostome, and is therefore less desirable. However, there is potential for development of this fishery given the dramatic abundances of this species, which can sometimes approach the biomass of small pelagic fishes in the region (Mianzan et al. 2014; Quiñones et al. 2015). Large blooms of $C$. plocamia are often a costly nuisance to fishers, aquaculture, desalination plants, tourism, and other industries (Quiñones et al. 2013; Mianzan et al. 2014), suggesting that many would welcome a targeted fishery in the area. Indeed, the nuisance of C. plocamia bycatch to fishers was one of the primary motivations to explore the development of a jellyfish fishery in the region. Similarly large abundances of $C$. plocamia also occur in northern Chile, suggesting that if a jellyfish fishery were to be established in Peru, expansion to Chile would be a possibility (Palma 2011). While there are preliminary indications that some buyers in China have found product samples from Peru to be satisfactory, a jellyfish fishery has yet to develop in the region.

\section{USA}

The United States of America has both active and discontinued jellyfish fisheries. Active fisheries involve cannonball jellyfish (Stomolophus meleagris) in the southeastern part of the country (see below). There was also a historical fishery for jellyfish in Washington State's Puget Sound, but instead of targeting jellyfish for food, that fishery sought the hydromedusan Aequorea victoria for research on bioluminescence. The tale is chronicled by Shimomura (1995), and includes the isolation of luminescent proteins 'aequorin' and 'green fluorescent protein' (GFP) in 1962 and 1979 respectively. GFP, which absorbs ultraviolet light and emits a green glow without the addition of any chemical additives, has 
proven to be an invaluable genetic marker, resulting in a veritable revolution in biotechnology (Zimmer 2005). This immense contribution to science was recognized in 2008, when the Nobel Prize in Chemistry was awarded for the discovery and development of GFP (Coleman 2010; Roda 2010). A. victoria has not been targeted from Puget Sound since the 1990s, as synthetic aequorin and GFP are now available. However, during the course of researching the luminescent proteins of A. victoria, it has been estimated that a total of one million medusae were collected over the 25 year period in Friday Harbor (Zimmer 2005). Taking the estimate of Shimomura (1995) of $50 \mathrm{~g}$ for a typical specimen, this equates to a total catch of approximately $50 \mathrm{t}$, or $2 \mathrm{t}$ per year. This is miniscule in the context of most jellyfish fisheries, which may catch tens of thousands or even hundreds of thousands of tonnes of jellyfish in a single season. However, it is worth noting that even these small annual catches may have affected the population of A. victoria around Friday Harbor. Upon Osamu Shimomura's arrival on San Juan Island in 1961, the medusae were reportedly "abundant" and provided a "constant stream" flowing passed the docks. However, it was observed that the abundance of this species began to decline in the 1990s (Mills 2001) and has since "almost completely disappeared from the area" (Shimomura 2005). The effects of this apparent overfishing do not appear to be widespread, as Aequorea populations in the nearby waters of British Columbia can form extensive blooms with occasional densities of $1-2$ medusae $/ \mathrm{m}^{3}$ (LB personal observations).

In the southeastern USA, cannonball jellyfish or 'jellyballs' ( $S$. meleagris) have been the source of numerous problems to industries such as power generation and fisheries. Due in part to the nuisance that jellyfish have caused to industry, there have been several attempts to establish fisheries for $S$. meleagris in the USA, with varying degrees of success. The first attempt was reportedly in Medart, Florida in the 1970s for export to Taiwan; however, the venture was unsuccessful, partially due to the reluctance of fishers to target jellyfish (Rudloe 1992). Interest was renewed in the late 1980s, both in Florida and Georgia. At the time, processing techniques were being investigated by Huang $(1986,1988)$ at the University of Georgia. In 1991, development of a jellyfish fishery was officially launched through a grant from the US Department of Commerce (USDC). Under the grant, marine scientist
Jack Rudloe traveled to Malaysia and Thailand to investigate jellyfish fishing and processing methods. Outlined in Rudloe (1992), a jellyfish fishery was proposed for the Florida Panhandle in the northern Gulf of Mexico, where commercial fisheries had suffered dramatic declines due to overfishing and rapid coastal development. The initial report concluded that a fishery for jellyfish could be developed in Florida; however, several challenges would have to be overcome, including economic viability, a lack of processing knowledge, labor costs, and pollution from processing facilities. An additional challenge proved to be the size of the product. Cannonball jellyfish from the region rarely exceed $19 \mathrm{~cm}$ in bell diameter, but jellyfish products fetching the highest prices at market at the time were $30 \mathrm{~cm}$ or more. Nevertheless, it was thought that a superior product could be produced from cannonball jellyfish and the exploration of the fishery in Florida continued.

Throughout the 1990s, a variety of attempts were made to develop the jellyfish fishery in Florida, whereby small quantities of jellyfish were landed, processed, and sent to potential buyers in Asia (Jones and Rudloe 1995). The darker color of Atlantic cannonball jellyfish was not preferred, and attention shifted to catching jellyfish in the Gulf of Mexico, which are white in color. Challenges for the emerging fishery continued, including high labor costs and an unfamiliarity with the species in Asia (Bynum 2003). Currently, 26 American fishing vessels target cannonball jellyfish in the Gulf of Mexico, with 11 operating out of Apalachicola and 15 out of Port Saint Joe.

The State of Georgia also has an established jellyfish fishery, which began in the 1990s with a solitary processing plant located in Darien (Graitcer 2012). Since 1998, licenses for catching jellyfish have been limited to 6-12 fishers (Page 2015), mainly due to limited processing capacity. The fishers involved in the jellyfish fishery are shrimpers that temporarily convert their boats to fish for jellyfish (Fig. 3), and are reportedly thankful for their newfound opportunity (Bynum 2003; Landers 2011). The jellyfish fishery in Georgia transitioned from experimental to a recognized fishery in 2013, and continues to operate at capacity with an estimated average annual catch around $4000 \mathrm{t}$ and the possibility of future expansion. Current catch levels make jellyfish the third largest fishery in Georgia by weight, behind shrimp and blue crab (Page 2015). 
Entrepreneurs in the state of South Carolina are eager to start catching, processing, and exporting cannonball jellyfish. However, development plans have been hampered by concerns over pollution from processing facilities. Proposals have been put forth in Beaufort and Colleton Counties, with capacity in excess of $2000 \mathrm{t}$ per week (Bland 2014). While approximately $6 \mathrm{t}$ of jellyfish were landed and processed at a temporary facility in 2014, these operations have ceased pending further review (Moody 2014; Murdock 2014).

\section{Management}

Jellyfish populations typically exhibit dramatic interannual variation (Brotz 2011). In fact, changes in biomass of edible jellyfish are probably larger than for any other fishery (Kingsford et al. 2000). This presents extremely large uncertainties for fisheries managers, makes predictions of future catches difficult, and may prevent investment in infrastructure. There is also evidence to suggest that discrete stocks of medusae may exist at relatively small spatial scales (Kingsford et al. 2000; Matsumura et al. 2005). This could make some populations vulnerable to overfishing, especially as fishers are likely to concentrate their effort in areas that are closer to ports or processing facilities (Kingsford et al. 2000). As such, management of jellyfish fisheries is extremely challenging, with research and recommendations still in their infancy. Nonetheless, many of the options for traditional fisheries management are available to jellyfish fisheries, only a few of which have been employed.

In Australia, precautionary total allowable catches (TACs) have been implemented (Fisheries Victoria and MAFRI 2002; Fisheries Victoria 2006), but only a small fraction of the TACs have been utilized, presumably due to a lack of economic viability and onerous regulations. TACs for jellyfish fisheries appear to be rare in most other countries; however, total catch may be limited by processing capacity where it is regulated or industrialized, as is the case in the USA. TACs can also be artificially increased if portions of the jellyfish, such as the oral arms, are discarded at sea. Some countries have also implemented minimum size limits (MSLs) on medusae, such as Australia, Mexico, and the USA. The intent of MSLs is to prevent the capture of medusae before they reach sexual maturity, as well as encouraging higher fecundity, which typically increases with size (e.g., Coleman 2004; Schiariti et al. 2012a). However, there is no guarantee that medusae will spawn successfully at a certain size, or that they will be in a location where planulae can find suitable substrate for settlement. Conversely, medusae may reach sexual maturity over a wide range of sizes, and maturation may be more related to environmental conditions than size (Carvalho-Saucedo et al. 2010, 2011). Of course, a medusa's size is also related to environmental conditions, so the interplay amongst the environment, a medusa's size, and its state of sexual maturity are not well understood. As such, MSLs are likely not enough to guarantee a sustainable jellyfish fishery (admittedly, nor are they sufficient for finfish fisheries). In addition, larger mesh sizes have the potential to damage the medusae, depending on the species in question and the gear used. Nevertheless, implementation of MSLs may be a useful precautionary management technique, especially when knowledge of the target organism's life history and environment is poor. MSLs can also have the added benefit of allowing jellyfish to grow before being caught, which may result in more profit as larger medusae typically fetch higher prices, unless of course natural mortality increases or the jellyfish exhibit degrowth due to poor food availability or other environmental conditions (e.g., Hamner and Jenssen 1974; Frandsen and Riisgard 1997; You et al. 2007; Lilley et al. 2014). Additional research on such topics is essential, especially the exploration of which management techniques are most appropriate for jellyfish fisheries. Due to the poor understanding of jellyfish population dynamics, management decisions for jellyfish fisheries should be adaptive and will likely vary from year to year, or even within a single season.

While the polymorphic life cycle of edible jellyfish (Fig. 2) likely provides a buffer against overfishing, it should not be viewed as a total safeguard. The impacts of fishing medusae on entire jellyfish populations are not well understood, and overfishing of jellyfish stocks appears possible. For example, overfishing of medusae appears to be the primary cause for the decline of Rhopilema esculentum in China (Dong et al. 2014), where there are now extensive aquaculture programs that culture this species in large saltwater ponds (You et al. 2007), as well as hatchery programs that rear hundreds of millions of individual ephyrae in laboratories and subsequently release them into the ocean 
with the intention of increasing the catch (Dong et al. 2009). Despite limited success from these programs (Dong et al. 2014), catches of $R$. esculentum in Chinese waters remain below the levels of the late 1990s, and effort has shifted to the increasingly abundant giant jellyfish, Nemopilema nomurai (Brotz and Pauly 2016).

Jellyfish fisheries are clearly growing and expanding faster than research and regulations on the subject. As such, there are a variety of knowledge gaps that should be a priority for researchers and managers that include, but are not limited to:

- Estimates of medusae abundance in regions where fishing occurs or is proposed to occur;

- Surveys to locate (and potentially protect) important polyp habitat;

- Investigations on the linkages between polyp density and medusae abundance;

- Studies on local populations of jellyfish (every species is different, and there are potential important differences even within species, e.g., dramatic differences in color and morphology between different varieties of $S$. meleagris);

- Investigations on the use of models for jellyfish fisheries (e.g., are traditional models for finfish applicable to jellyfish fisheries?);

- Monitoring and tracking of medusae to identify the factors that control aggregations and mixing of stocks;

- Genetic analyses to determine discrete stocks and mixing of populations;

- Investigations of ephyrae growth and survival.

\section{Conclusions and recommendations}

Jellyfish have undergone a dramatic transition in some locations in the Americas, often shifting from being a nuisance to industries such as fisheries, tourism, and power generation to being a valuable fishery resource. In most cases, this transition was preceded by a decline of more traditional fisheries resources such as finfish and shrimp. So, should this transition be celebrated as an example of adaptability, or is it another warning sign of fishing down the food web (Pauly et al. 1998)? And what factors dictate the overall success or failure of such a transition? After all, jellyfish fisheries have clearly arrived in the Americas, but with varying degrees of success. For example, jellyfish fisheries in the USA and especially Mexico have proven to be a boon for local fishers (Álvarez-Tello 2007; LópezMartinez and Álvarez-Tello 2013), whereas no market has yet developed for jellyfish from Argentina, Canada, or Peru.

There appear to be a number of factors that are conducive to success for new jellyfish fisheries in the short term, and several additional recommendations that may help to ensure establishment of sustainable jellyfish fisheries in the longer term. Firstly, not just any species of jellyfish will do. There are more than 1400 species of jellyfish worldwide (Purcell 2012), but fewer than 40 of those have been documented as being consumed by humans (Table 2). In fact, the number of jellyfish species that are part of major jellyfish fisheries around the world number fewer than 20, and are all rhizostomes (Brotz 2016). While it is conceivable that consumption of semeaostomes and other types of jellyfish may increase in the future, demand for non-rhizostome jellyfish currently remains very low and is likely a major reason why experimental jellyfish fisheries in Canada and Peru were not successful.

Secondly, attention must be paid to the processing of jellyfish. In order to ensure economic success, specific details regarding the nuances of jellyfish processing should come from potential buyers, likely in Asia. As mentioned, the methods and materials used can vary greatly due to a number of factors, so potential exporters need to work closely with buyers to deliver a suitable product. Jellyfish processing is typically labor intensive, so the time and effort required will have to be factored into the economics of any operation, especially in regions where labor costs are high. Jellyfish fisheries in the USA appear to have overcome this obstacle by a combination of the development of shorter processing times through technical advances and the use of smaller medusae, as well as partial industrialization of processing. Moreover, there are significant environmental and human health concerns regarding the contemporary use of processing chemicals. Large quantities of effluent are generated as a byproduct of jellyfish processing, and need to be dealt with in a responsible way. Edible jellyfish may contain concerning amounts of aluminum (Wong et al. 2010; Ogimoto et al. 2012; Armani et al. 2013; Zhang et al. 2016), the consumption of which is linked to a number of negative health 
effects, including Alzheimer's disease (Perl and Brody 1980; Nayak 2002). The development of new processing technologies that either reduce the aluminum content in the edible products (e.g., Chen et al. 2016) or eliminate the use of alum altogether is desirable (Hsieh and Rudloe 1994). Such research could easily be undertaken by the vast array of food scientists in industry and academia. As an example, Cotylorhiza tuberculata that was frozen fresh at ultra-low temperature (close to $-80{ }^{\circ} \mathrm{C}$ ) and then reconstituted by a professional chef with a small amount of sugar and vinegar was declared to be delectable by one of us (LB). As the seafood industry already has significant infrastructure for freezing, storage, and distribution of food, this may provide an alternative to chemical processing of jellyfish in some places. The development of alternative processing technologies could provide multiple benefits for jellyfish fisheries, including expansion beyond rhizostome species, development of new markets, reduced costs, and the elimination of environmental and human health concerns.

To ensure success of jellyfish fisheries in the longer-term, cooperation between stakeholders appears to be key. In addition to the collaboration between processors and buyers mentioned above, fishers, managers, and researchers all need to work together to help ensure the sustainability of jellyfish fisheries. If it is hoped that jellyfish can fill some of the void left by the collapses of more traditional fisheries, much more research will be required if repeating history is to be avoided. Understanding of jellyfish population dynamics remains extremely poor, and as such, the development of management strategies for jellyfish fisheries continues to be a challenge. Collection of even the most basic fishery data, such as catch amounts, dates, and locations remains poor (Kingsford et al. 2000; Brotz and Pauly 2016), greatly limiting the advancement of research and development of management plans. Given the inverse seasons of the northern and southern hemispheres, the Americas are in a position to provide a reliable source of jellyfish to Asia year-round. However, if a sustainable supply is to be achieved, much remains to be learned. Detailed studies at local scales will help shed light on basic questions, and a shift towards ecosystem-based management would contribute to building knowledge of the interactions between the resource and the environment, as well as helping to quantify the impacts of developing a fishery. Fluctuations in market demand also present additional challenges. Interest in importing jellyfish to Asian countries is highest when the supply of jellyfish is low in Asian waters, which is subject to large variability on seasonal and interannual timescales. Competition for buyers between different jellyfish fisheries in the Americas will also have to be addressed, as was evidenced by the reduced demand for jellyfish from Mexico in 2014, which was due in part to the new supply from Ecuador and Nicaragua. Market demand from particular areas can also be affected by product quality. For example, some jellyfish from Central America may have more denticulations on the bell surface, ultimately leading to undesirable "spots" on the final product. Inexperienced or shoddy processors may also produce a dehydrated jellyfish product that is inferior, potentially causing buyers to turn away from particular regions altogether. Given such challenges of a newfound industry that is constantly in flux, it is clear that market dynamics should be added to the list of knowledge gaps for jellyfish fisheries in the Americas, and future research programs need to consider economic components as well as ecological ones.

Given the extreme variability of jellyfish populations (Brotz 2011), along with additional factors that contribute to high uncertainty in jellyfish fisheries (Kingsford et al. 2000), ensuring long-term sustainability of jellyfish fisheries will likely be difficult. As such, managers should consider employing conservative strategies that may include catch limits, size limits, adaptive management, harvest control rules, the precautionary principle, and the protection of polyp habitat. Combined with economic drivers and concerns related to processing technologies, management of jellyfish fisheries will surely continue to be a challenge.

As jellyfish populations are increasing in many areas of the world (Brotz et al. 2012), it is likely that humans will look for new ways to exploit them. Although increasing abundances of jellyfish will bring some benefits to humans including jellyfish fisheries (Doyle et al. 2014), it has been submitted that the costs associated with the negative impacts of jellyfish blooms will outpace any increased revenues (Graham et al. 2014). Indeed, it is only by increasing our understanding of these understudied creatures through collaboration between fishers, managers, researchers, processors, brokers, and buyers that we will be able to 
minimize the impacts and maximize the opportunities offered by future jellyfish blooms.

Acknowledgments We dedicate this paper to Dr. Hermes Mianzan, our friend and perpetual inspiration, who always wondered if a jellyfish fishery would be possible in South America. This paper was written because of him and for him. He is missed, but he lives on in our hearts. We thank Dr. Antonella Leone, Dr. Stefano Piraino, and chef Gennaro Esposito for introducing us to alternative preparations of edible jellyfish. This is a contribution from the Sea Around Us, a research program supported by The Pew Charitable Trusts and The Paul G. Allen Family Foundation. This paper has been partially funded by CONICET PIP 2013-00615 and PICT 2013-1773. This is CONACYT 249458 Project contribution. This is INIDEP contribution No. 1930. ACM was supported by grants 2010/50174-7, 2011/50242-5, and 2013/50484-4 São Paulo Research Foundation (FAPESP), and by CNPq (301039/20135). This is a contribution of NP-BioMar, USP.

\section{References}

Addad S, Exposito J-Y, Faye C, Ricard-Blum S, Lethias C (2011) Isolation, characterization and biological evaluation of jellyfish collagen for use in biomedical applications. Mar Drugs 9:967-983

Adler L, Jarms G (2009) New insights into reproductive traits of scyphozoans: special methods of propagation in Sanderia malayensis enable establishing a new classification of asexual reproduction in the class Scyphozoa. Mar Biol 156:1411-1420

Álvarez-Tello FJ (2007) La pesquería de al medusa bola de cañón (Stomolophus meleagris) en la región de Kino-El Choyudo, Sonora, durante 2006. Master's thesis, Instituto Tecnológico de Guaymas, Sonora, Mexico (in Spanish)

Álvarez-Tello FJ, López-Martínez J, Rodríguez-Romero J (2013) First record of the association between Stomolophus meleagris and Conchoderma cf virgatum in the Gulf of California. Hidrobiologica 23:138-142 (in Spanish)

Appeltans W, Ahyong ST, Anderson G, Angel MV, Artois T, Bailly N, Bamber R, Barber A, Bartsch I, Berta A et al (2012) The magnitude of global marine species diversity. Curr Biol 22:2189-2202

Arai MN (1988) Interactions of fish and pelagic coelenterates. Can J Zool 66:1913-1927

Arai MN (1997) A functional biology of scyphozoa. Chapman and Hall, London

Arai MN (2005) Predation on pelagic coelenterates: a review. J Mar Biol Assoc UK 85:523-536

Arai MN (2009) The potential importance of podocysts to the formation of scyphozoan blooms: a review. Hydrobiologia 616:241-246

Armani A, Tinacci L, Giusti A, Castigliego L, Gianfaldoni D, Guidi A (2013) What is inside the jar? Forensically informative nucleotide sequencing (FINS) of a short mitochondrial COI gene fragment reveals a high percentage of mislabeling in jellyfish food products. Food Res Int 54:1383-1393
Ates RML (1988) Medusivorous fishes - a review. Zool Meded (Leiden) 62:29-42

Bakun A, Weeks SJ (2006) Adverse feedback sequences in exploited marine systems: are deliberate interruptive actions warranted? Fish Fish 7:316-333

Balamurugan E, Reddy BV, Menon VP (2010) Antitumor and antioxidant role of Chrysaora quinquecirrha (sea nettle) nematocyst venom peptide against ehrlich ascites carcinoma in Swiss Albino mice. Mol Cell Biochem 338: 69-76

Bayha KM, Graham WM (2011) First confirmed reports of the rhizostome jellyfish Mastigias in the Atlantic basin. Aquat Invasions 6:361-366

Bland A (2014) Southern fishermen cash in on Asia's taste for jellyfish. The Salt, National Public Radio

Bolton TF, Graham WM (2004) Morphological variation among populations of an invasive jellyfish. Mar Ecol Prog Ser 278:125-139

Brandon M, Cutress CE (1985) A new Dondice (Opisthobranchia: Favorinidae), predator of Cassiopea in southwest Puerto Rico. Bull Mar Sci 36:139-144

Broadhurst MK, Kennelly SJ (1996) Rigid and flexible separator panels in trawls that reduce the by-catch of small fish in the Clarence River prawn-trawl fishery, Australia. Mar Freshw Res 47:991-998

Brodeur RD (1998) In situ observations of the association between juvenile fishes and scyphomedusae in the Bering Sea. Mar Ecol Prog Ser 163:11-20

Brotz L (2011) Changing jellyfish populations: trends in Large Marine Ecosystems. Fisheries Centre Research Report 19(5), Fisheries Centre, University of British Columbia, Vancouver, Canada

Brotz L (2016) Jellyfish fisheries-a global assessment. In: Pauly D, Zeller D (eds) Global atlas of marine fisheries: a critical appraisal of catches and ecosystem impacts. Island Press, Washington, D.C., USA, pp 110-124

Brotz L, Pauly D (2012) Jellyfish populations in the Mediterranean sea. Acta Adriat 53:211-230

Brotz L, Pauly D (2016) Studying jellyfish fisheries: toward accurate national catch reports and appropriate methods for stock assessments. In: Mariottini GL (ed) Jellyfish: ecology, distribution patterns and human interactions. Nova Publishers, Hauppauge

Brotz L, Cheung WWL, Kleisner K, Pakhomov E, Pauly D (2012) Increasing jellyfish populations: trends in large marine ecosystems. Hydrobiologia 690:3-20

Browne JG, Kingsford MJ (2005) A commensal relationship between the scyphozoan medusae Catostylus mosaicus and the copepod Paramacrochiron maximum. Mar Biol 146:1157-1168

Bynum R (2003) Jellyfish help shrimpers to survive tough market. Rome News-Tribune, Rome, Georgia, USA

Calder DR (1973) Laboratory observations on the life history of Rhopilema verrilli. Mar Biol 21:109-114

Calder DR (1982) Life history of the cannonball jellyfish, Stomolophus meleagris. Biol Bull 162:149-162

Calder DR (2009) Cubozoan and scyphozoan jellyfishes of the Carolinian biogeographic province, Southeastern USA. Royal Ontario Museum Contributions in Science, Toronto, Canada, $58 \mathrm{pp}$ 
Cardona L, de Quevedo IA, Borrell A, Aguilar A (2012) Massive consumption of gelatinous plankton by Mediterranean apex predators. PLoS One 7:e31329

Carvalho-Saucedo L, García-Domínguez F, Rodríguez-Jaramillo C, López-Martinez J (2010) Lipid variation in oocytes of the jellyfish Stomolophus meleagris from Las Guasimas Lagoon, Mexico, during gonadal development. Revista De Biología Tropical 58:119-130 (in Spanish with English abstract)

Carvalho-Saucedo L, López-Martinez J, García-Domínguez F, Rodríguez-Jaramillo C, Padilla-Serrato J (2011) Reproductive biology of the cannonball jellyfish Stomolophus meleagris in Las Guasimas Lagoon, Sonora, Mexico. Hidrobiologica 21:77-88 (in Spanish with English abstract)

Carvalho-Saucedo L, López-Martínez J, García-Domínguez F (2012) Stomolophus meleagris fecundity in the Gulf of California. Rev Biol Trop 60:1721-1729 (in Spanish with English abstract)

Cedeño-Posso CM, Lecompte Pérez OP (2013) First record of the jellyfish of the genus Lychnorhiza in the Colombian Caribbean. Bol Investig Mar Costeras 42:387-393 (in Spanish with English abstract)

Chen J-W, Li X-Y, Qin P, Wang H-P, Ma X, Yin F, Wang Q-M (2016) Removal technology of aluminum in production process of jellyfish. J Food Saf Qual 7:1681-1685 (in Chinese with English abstract)

Chidambaram L (1984) Export oriented processing of Indian jelly fish (Muttai Chori, Tamil) by Indonesian Method at Pondicherry Region. Technical and Extension Series (60). Marine Fisheries Information Service, Central Marine Fisheries Research Institute, Indian Council of Agricultural Research, Cochin, India, pp 11-13

Chun KW, Damdinsuren E, Yeom K, Ezaki T (2011) Effect of jellyfish fertilizer application on seedling growth. J Jpn Soc Revege Technol 37:155-158

CIESM (2010) New partnerships for blue biotechnology development-innovative solutions from the sea. Briand $\mathrm{F}$ (ed), Report on CIESM international workshop, Monaco, 11-12 Nov 2010, The Mediterranean Science Commission, $44 \mathrm{pp}$

Coleman N (2004) Jellyfish fishery development and assessment 1999/138. Primary Industries Research Victoria, Marine and Freshwater Systems, Department of Primary Industries, Victoria, Australia, $120 \mathrm{pp}$

Coleman R (2010) Jellyfish, fluorescent proteins, Nobel Prizes and pioneers in histochemistry. Acta Histochem 112:113-117

Coleman A, Micin S, Mulvay P, Rippingale R (1990) The brown jellyfish (Phyllorhiza punctata) in the Swan-Canning estuary. Waterways Information No. 2. Swan River Trust, Perth, Australia, 4 pp

Dabiri JO (2011) Jellyfish-inspired propulsion. Integr Comp Biol 51:E29

DFA (2002a) Production and marketing of jellyfish. Project summary: FDP 421-3, Emerging Fisheries Development, Fisheries Diversification Program. Department of Fisheries and Aquaculture, Government of Newfoundland and Labrador, Canada, 2 pp

DFA (2002b) Jellyfish exploratory survey, Trinity Bay. Project summary: FDP 424-5, Emerging Fisheries Development,
Fisheries Diversification Program. Department of Fisheries and Aquaculture, Government of Newfoundland and Labrador, Canada, 4 pp

Dong J, Jiang LX, Tan KF, Liu HY, Purcell JE, Li PJ, Ye CC (2009) Stock enhancement of the edible jellyfish (Rhopilema esculentum) in Liaodong Bay, China: a review. Hydrobiologia 616:113-118

Dong ZJ, Liu DY, Keesing JK (2010) Jellyfish blooms in China: dominant species, causes and consequences. Mar Pollut Bull 60:954-963

Dong Z, Liu D, Keesing JK (2014) Contrasting trends in populations of Rhopilema esculentum and Aurelia aurita in Chinese waters. In: Pitt KA, Lucas CH (eds) Jellyfish blooms. Springer, Dordrecht, Netherlands, pp 207-218

Doyle TK, Hays GC, Harrod C, Houghton JDR (2014) Ecological and societal benefits of jellyfish. In: Lucas CH, Pitt KA (eds) Jellyfish blooms. Springer, Dordrecht, Netherlands, pp 105-127

Duarte CM, Pitt KA, Lucas CH, Purcell JE, Uye S, Robinson K, Brotz L, Decker MB, Sutherland KR, Malej A et al (2013) Is global ocean sprawl a cause of jellyfish blooms? Front Ecol Environ 11:91-97

Duron-Dufrenne M (1987) Premier suivi par satellite en Atlantique d'une torue luth Dermochelys coriacea. Comptes Rendus Acad des Sci Paris 304:339-402 (in French)

Fisheries Victoria, MAFRI (2002) Developmental Fisheries Management Plan, Jellyfish (Catostylus mosaicus), 2003-2005. Fisheries Victoria and the Marine and Freshwater Resources Institute, Fisheries Division, Department of Natural Resources and Environment, Victoria, Australia, $15 \mathrm{pp}$

Fisheries Victoria (2006) Statement of management arrangements for the Victorian developmental jellyfish fishery (Catostylus mosaicus). Statement prepared for the Australian Department of Hertiage and Environment. Fisheries Victoria Division of the Department of Primary Industries, Victoria, Australia, $15 \mathrm{pp}$

Fleming NEC, Harrod C, Griffin DC, Newton J, Houghton JDR (2014) Scyphozoan jellyfish provide short-term reproductive habitat for hyperiid amphipods in a temperate nearshore environment. Mar Ecol Prog Ser 510:229-240

Flynn BA, Richardson AJ, Brierley AS, Boyer DC, Axelsen BE, Scott L, Moroff NE, Kainge PI, Tjizoo BM, Gibbons MJ (2012) Temporal and spatial patterns in the abundance of jellyfish in the northern Benguela upwelling ecosystem and their link to thwarted pelagic fishery recovery. Afr J Mar Sci 34:131-146

Frandsen KT, Riisgard HU (1997) Size dependent respiration and growth of jellyfish, Aurella aurita. Sarsia 82:307-312

Fukushi K, Ishio N, Tsujimoto J, Yokota K, Hamatake T, Sogabe H, Toriya K, Ninomiya T (2004) Preliminary study on the potential usefulness of jellyfish as fertilizer. Bull Soc Sea Water Sci Jpn 58:209-217

Fukushi K, Tsujimoto J, Yokota K (2005) Determination of inorganic constituents in jellyfish. Bunseki Kagaku 54:175-178 (in Japanese with English abstract)

Garcia JR (1990) Population dynamics and production of Phyllorhiza punctata in Laguna Joyuda, Puerto Rico. Mar Ecol Prog Ser 64:243-251

Gemmell BJ, Costello JH, Colin SP, Stewart CJ, Dabiri JO, Tafti D, Priya S (2013) Passive energy recapture in jellyfish 
contributes to propulsive advantage over other metazoans. Proc Natl Acad Sci USA 110:17904-17909

Gibbons MJ, Boero F, Brotz L (2016) We should not assume that fishing jellyfish will solve our jellyfish problem. ICES J Mar Sci 73:1012-1018

Gopakumar, G, Madhu, K, Jayashankar, R, Madhu, R, Kizhakudan, JK, Jose, J, Ignatius, B, Vijayagopal, P, Joseph, S, Mohamed, G, et al. (2008) Live feed research for larviculture of marine finfish and shellfish. Marine Fisheries Information Service (197), Technical and Extension Series. Central Marine Fisheries Research Institute, Indian Council of Agricultural Research, Cochin, India, pp 1-6

Govindan TK (1984) A novel marine animal with much export potential. Seaf Export J 16:9-11

Graham WM, Pages F, Hamner WM (2001) A physical context for gelatinous zooplankton aggregations: a review. Hydrobiologia 451:199-212

Graham WM, Gelcich S, Robinson KL, Duarte CM, Brotz L, Purcell JE, Madin LP, Mianzan H, Sutherland KR, Uye S et al (2014) Linking human well-being and jellyfish: ecosystem services, impacts, and societal responses. Front Ecol Environ 12:515-523

Graitcer P (2012) US Jellyfish land on Asian dinner tables. Voice of America, Washington, D.C., USA

Grocock C, Grainger S (2006) Apicius - a critical edition with an introduction and an English translation of the Latin recipe text Apicius. Prospect Books, Devon, United Kingdom, $414 \mathrm{pp}$

Gul S, Morandini AC (2013) New records of scyphomedusae from Pakistan coast: Catostylus perezi and Pelagia cf. noctiluca. Mar Biodivers Rec 6:1-6

Gul S, Morandini AC (2015) First record of the jellyfish Rhopilema hispidum from the coast of Pakistan. Mar Biodivers Rec 8:1-4

Haddad MA, Nogueira M Jr (2006) Reappearance and seasonality of Phyllorhiza punctata medusae in southern Brazil. Rev Bras Zool 23:824-831

Haeckel E (1880) Das System der Medusen, Erster Theil einer Monographie der Medusen. Zweite Halfte des Ersten Thiels; System der Acraspeden. Denk. Ges. Jena, 672 pp

Hamner WM, Jenssen RM (1974) Growth, degrowth, and irreversible cell differentiation in Aurelia aurita. Am Zool 14:833-849

Heaslip SG, Iverson SJ, Bowen WD, James MC (2012) Jellyfish support high energy intake of leatherback sea turtles (Dermochelys coriacea): video evidence from animalborne cameras. PLoS One 7:e33259

Heeger T (1998) Quallen. Gefährliche Schönheiten. Stuttgart, Wissenschaftliche Verlagsgesellschaft $\mathrm{mbH}$, Stuttgart, Germany

Henschke N, Bowden DA, Everett JD, Holmes SP, Kloser RJ, Lee RW, Suthers IM (2013) Salp-falls in the Tasman Sea: a major food input to deep-sea benthos. Mar Ecol Prog Ser 491:165-175

Herrera FMA (2015) Explotación de medusa y trasformación del paisaje natural y cultural en Kaukira. La Tribuna, Tegucigalpa, Honduras, August 21 (in Spanish)

Hofmann DK, Hadfield MG (2002) Hermaphroditism, gonochorism, and asexual reproduction in Cassiopea sp.-an immigrant in the islands of Hawai'i. Invertebr Reprod Dev 41:215-221
Holland BS, Dawson MN, Crow GL, Hofmann DK (2004) Global phylogeography of Cassiopea: molecular evidence for cryptic species and multiple invasions of the Hawaiian Islands. Mar Biol 145:1119-1128

Hong H (2002) The jellyfish and Rhopilema esculentum. Biol Bull 37:13-16 (in Chinese)

Hossain ST, Sugimoto H, Asagi N, Araki T, Ueno H, Morokuma M, Kato H (2013) The use of desalinated-dried jellyfish and rice bran for controlling weeds and rice yield. J Org Syst 8:28-37

Hsieh YHP (2005) Use of jellyfish collagen (type II) in the treatment of rheumatoid arthritis. United States Patent Number No. 6,894,029. Auburn University, May 17

Hsieh YHP, Rudloe J (1994) Potential of utilizing jellyfish as food in Western countries. Trends Food Sci Technol 5:225-229

Hsieh YHP, Leong FM, Rudloe J (2001) Jellyfish as food. Hydrobiologia 451:11-17

Huang Y (1986) The processing of cannonball jellyfish (Stomolophus meleagris) and its utilization. In: Proceedings of the 11th annual tropical and subtropical fisheries technological conference of the Americas, January 13-16, 1986. Tampa, FL, USA

Huang Y (1988) Cannonball jellyfish (Stomolophus meleagris) as a food resource. J Food Sci 53:341-343

Huang Y, Christian P, Colson D (1987) Harvest and preservation of a shrimp by-catch: cannonball jellyfish (Stomolophus meleagris). In: Proceedings of the 12th annual tropical and subtropical fisheries technological conference of the Americas, November 9-11, 1987. Orlando, FL, USA

Hummelinck PW (1968) Carribean Scyphomedusae of the genus Cassiopea. Stud Fauna Curaçao Other Caribb Islands 25:1-57

Hussein OS, Saleh OI (2014) Effect of soaking in jellyfish on some parameters of wheat and lentil seedlings. J Environ Sci Toxicol Food Technol 8:32-39

Hussein OS, Sayed RM, Saleh OI (2015) Uses of jellyfish in pre sowing seeds treatment and pest control. Am J Exp Agric 5:60-69

Imamura K, Tsuruta D, Tsuchisaka A, Mori T, Ohata C, Furumura M, Hashimoto T (2013) Anaphylaxis caused by ingestion of jellyfish. Eur J Dermatol 23:392-395

Inomata N, Chin K, Aihara M (2014) Anaphylaxis caused by ingesting jellyfish in a subject with fermented soybean allergy: possibility of epicutaneous sensitization to polygamma-glutamic acid by jellyfish stings. J Dermatol 41:752-753

Jenkins L (2012) Reducing sea turtle bycatch in trawl nets: a history of NMFS turtle excluder device (TED) research. Mar Fish Rev 74:26-44

Jones S (1960) Notes on animal associations. 2. The scyphomedusa, Acromitus ftagellatus and young Steroides leptolepis with the latter forming a vanguard. J Mar Biol Assoc India 2:51-52

Jones RP, Rudloe J (1995) Harvesting \& processing of Florida cannonball jellyfish. Report to the Florida International Affairs Commission, Florida Department of Commerce. Southeastern Fisheries Association, Tallahassee, Florida, USA, $28 \mathrm{pp}$

Kailola PJ, Williams MJ, Stewart PC, Reichelt RE, McNee A, Grieve C (1993) Australian Fisheries Resources. Bur Resour Sci Fish Res Dev Corp, Canberra, Australia, 422 pp 
Kawabata T, Lindsay DJ, Kitamura M, Konishi S, Nishikawa J, Nishida S, Kamio M, Nagai H (2013) Evaluation of the bioactivities of water-soluble extracts from twelve deepsea jellyfish species. Fish Sci 79:487-494

Kelsey M (2009) Stinging intruders-invasive jellyfish removed from Kaunakakai wharf. The Molokai Dispatch, Kaunakakai, Hawaii, USA

Kikinger R (1992) Cotylorhiza tuberculata-life history of a stationary population. Mar Ecol 13:333-362

Kim Y-R, Kim S-W, Damdinsuren E, Ezaki T, Chun KW (2012) The effect of jellyfish (Nemopilema nomurai) fertilizer on tree growth in hillside erosion control works. J Forest Environ Sci 28:227-231

Kingsford MJ (1993) Biotic and abiotic structure in the pelagic environment-importance to small fishes. Bull Mar Sci 53:393-415

Kingsford MJ, Pitt KA, Gillanders BM (2000) Management of jellyfish fisheries, with special reference to the order Rhizostomeae. Oceanogr Mar Biol 38:85-156

Kitamura M, Omori M (2010) Synopsis of edible jellyfishes collected from Southeast Asia, with notes on jellyfish fisheries. Plankton Benthos Res 5:106-118

Kramp PL (1970) Zoogeographical studies on Rhizostomeae. Videnskabelige Meddelelser fra Dansk Naturhistorisk Forening 133:7-30

Kuthalingam, MDK, James, DB, Sarvesan, R, Devadoss, P, Manivasagam, S and Thirumilu, P (1989) A note on the processing of the jelly fish at Alambaraikuppam near Mahabalipuram. Marine Fisheries Information Service, Technical and Extension Series (98). Central Marine Fisheries Research Institute, Indian Council of Agricultural Research. Cochin, India, pp 8-10

Landers M (2011) Coastal Georgia shrimpers turn to jellyfish to make money. Savannah Morning News, Savannah, Georgia, USA

Larson RJ (1990) Scyphomedusae and Cubomedusae from the Eastern Pacific. Bull Mar Sci 47:546-556

Larson RJ, Arneson AC (1990) Two medusae new to the coast of California: Carybdea marsupialis, a Cubomedusa and Phyllorhiza punctata, a Rhizostome Scyphomedusa. Bull South Calif Acad Sci 89:130-136

Lebrato M, Pitt KA, Sweetman AK, Jones DOB, Cartes JE, Oschlies A, Condon RH, Molinero JC, Adler L, Gaillard C et al (2012) Jelly-falls historic and recent observations: a review to drive future research directions. Hydrobiologia 690:227-245

Lebrato M, Mendes PdJ, Steinberg DK, Cartes JE, Jones BM, Birsa LM, Benavides R, Oschlies A (2013) Jelly biomass sinking speed reveals a fast carbon export mechanism. Limnol Oceanogr 58:1113-1122

Leone A, Lecci RM, Durante M, Meli F, Piraino S (2015) The bright side of gelatinous blooms: nutraceutical value and antioxidant properties of three Mediterranean jellyfish (Scyphozoa). Mar Drugs 13:4654-4681

Lesson RP (1830) Zoophytes. In: Lesson M (ed) Voyage autour du monde, exécuté par ordre du Roi, sur la Covette de la Majesté, La Coquile, pendant les annèes 1822, 1823, 1824 et 1825 . Arthus Bertrand, Paris, France

Li J, Ling J, Cheng J (2014) On utilization of two edible macrojellyfish and evaluation of the biomass of Nemopilema nomurai in China Sea. Mar Fish 36:202-207 (in Chinese with English abstract)

Lilley MKS, Elineau A, Ferraris M, Thiery A, Stemmann L, Gorsky G, Lombard F (2014) Individual shrinking to enhance population survival: quantifying the reproductive and metabolic expenditures of a starving jellyfish, Pelagia noctiluca. J Plankton Res 36:1585-1597

Liu Y (1973) Study on processing technology of jellyfish. Fish Sci Technol Inf 1:16-17 (in Chinese)

López-Martinez J, Álvarez-Tello J (2013) The jellyfish fishery in Mexico. Agric Sci 4:57-61

López-Martínez J, Rodríguez-Romero J (2008) First record of association of the blackfin jack Hemicaranx zelotes with the cannonball jellyfish Stomolophus meleagris in Kino Bay, Gulf of California. Hidrobiologica 18:173-176 (in Spanish)

Lu Z, Dai Q, Yan Y (2003) Fishery biology of Cyanea nozakii resources in the waters of Dongshan Island. Chin J Appl Ecol 14:973-976 (in Chinese with English abstract)

Lucas CH, Graham WM, Widmer C (2012) Jellyfish life histories: role of polyps in forming and maintaining scyphomedusa populations. Adv Mar Biol 63:133-196

Lucas CH, Gelcich S, Uye S-I (2014) Living with jellyfish: management and adaptation strategies. In: Lucas CH, Pitt KA (eds) Jellyfish Blooms. Springer, Dordrecht, Netherlands, pp 129-150

Lynam CP, Gibbons MJ, Axelsen BE, Sparks CAJ, Coetzee J, Heywood BG, Brierley AS (2006) Jellyfish overtake fish in a heavily fished ecosystem. Curr Biol 16:R492-R493

Mariottini GL, Pane L (2010) Mediterranean jellyfish venoms: a review on scyphomedusae. Mar Drugs 8:1122-1152

Masuda A, Baba T, Dohmae N, Yamamura M, Wada H, Ushida K (2007) Mucin (Qniumucin), a glycoprotein from jellyfish, and determination of its main chain structure. J Nat Prod 70:1089-1092

Matsumura K, Kamiya K, Yamashita K, Hayashi F, Watanabe I, Murao Y, Miyasaka H, Kamimura N, Nogami M (2005) Genetic polymorphism of the adult medusae invading an electric power station and wild polyps of Aurelia aurita in Wakasa Bay, Japan. J Mar Biol Assoc UK 85:563-568

Mayer AG (1910) Medusae of the world-Vol. III. The Scyphomedusae. Carnegie Institution of Washington Publication No 109, Vol. III, pp 499-735

Mianzan HW, Cornelius PFS (1999) Cubomedusae and Scyphomedusae. In: Boltovskoy D (ed) South atlantic zooplankton, vol 1. Backhuys Publishers, Leiden, pp 513-559

Mianzan H, Pájaro M, Colombo GA, Madirolas A (2001) Feeding on survival-food: gelatinous plankton as a source of food for anchovies. Hydrobiologia 451:45-53

Mianzan H, Quiñones J, Palma S, Schiariti A, Marcelo Acha E, Robinson KL, Graham WM (2014) Chrysaora plocamia: a poorly understood jellyfish from South America. In: Pitt KA, Lucas CH (eds) Jellyfish blooms. Springer, Dordrecht, Netherlands, pp 219-236

Mills CE (1995) Medusae, siphonophores, and ctenophores as planktivorous predators in changing global ecosystems. ICES J Mar Sci 52:575-581

Mills CE (2001) Jellyfish blooms: are populations increasing globally in response to changing ocean conditions? Hydrobiologia 451:55-68 
Miyajima Y, Masuda R, Kurihara A, Kamata R, Yamashita Y, Takeuchi T (2011a) Juveniles of threadsail filefish, Stephanolepis cirrhifer, can survive and grow by feeding on moon jellyfish Aurelia aurita. Fish Sci 77:41-48

Miyajima Y, Masuda R, Yamashita Y (2011b) Feeding preference of threadsail filefish Stephanolepis cirrhifer on moon jellyfish and lobworm in the laboratory. Plankton Benthos Res 6:12-17

Mohan, S, Rajapackiam, S and Rajan, S (2011) Unusual heavy landings of jellyfish Crambionella stuhlmanni and processing methods at Pulicat landing centre, Chennai. Marine Fisheries Information Service Technical and Extension Series (208). Marine Fisheries Information Service (208), Technical and Extension Series. Central Marine Fisheries Research Institute, Indian Council of Agricultural Research, Cochin, India, pp 27-29

Möller H (1980) Scyphomedusae as predators and food competitors of larval fish. Meeresforschung 28:90-100

Moody E (2014) Jellyfish operation brings in catch, catches DHEC's attention. The Beaufort Gazette, Bluffton, South Carolina, USA

Morabito R, Dossena S, La Spada G, Marino A (2014) Heavy metals affect nematocysts discharge response and biological activity of crude venom in the jellyfish Pelagia noctiluca. Cell Physiol Biochem 34:244-254

Morandini AC (2009) Lychnorhiza lucerna: proposed conservation of generic and specific names. Bull Zool Nomencl 66:242-246

Morandini AC, Ascher D, Stampar SN, Ferreira JFV (2005) Cubozoa and Scyphozoa from Brazilian coastal waters. Iheringia Ser Zool 95:281-294 (in Portuguese)

Moreira MGBS (1961) Sôbre Mastigias scintillae sp. nov. das costas do Brasil. Boletim do Instituto Oceanogràfico 11:5-30 (in Portuguese)

Morikawa T (1984) Jellyfish. FAO INFOFISH Mark Digest 1:37-39

Morishige H, Sugahara T, Nishimoto S, Muranaka A, Ohno F, Shiraishi R, Doi M (2011) Immunostimulatory effects of collagen from jellyfish in vivo. Cytotechnology 63:481-492

Muhammed F, Sultana R (2008) New record of edible jellyfish, Rhizostoma pulmo from Pakistani waters. Mar Biodivers Rec 1:1-3

Murdock Z (2014) Jellyfish operations suspended pending state reviews. The Beaufort Gazette, Bluffton, South Carolina, USA

Murugan A, Durgekar R (2008) Beyond the Tsunami: Status of Fisheries in Tamil Nadu, India: a snapshot of present and Long-term Trends. United Nations Development Programme and Ashoka Trust for Research in Ecology and the Environment, Bangalore, India, 75 pp

Nagata RM, Haddad MA, Nogueira M Jr (2009) The nuisance of medusae (Cnidaria, Medusozoa) to shrimp trawls in central part of southern Brazilian Bight, from the perspective of artisanal fishermen. Pan Am J Aquat Sci 4:312-325

Najem J, Sarles SA, Akle B, Leo DJ (2012) Biomimetic jellyfish-inspired underwater vehicle actuated by ionic polymer metal composite actuators. Smart Mater Struct 21:094026

NARA (2010) Press statement on recent occurrence of jellyfish on south west coast. Natl Aquat Resour Res Dev Agency, Sri Lanka
Nayak P (2002) Aluminum: impacts and disease. Environ Res 89:101-115

Nevárez López CA (2010) Genetic characterization of phenotypes of the cannonball jellyfish (Stomolophus meleagris) in the central coast of Sonora. Thesis, Universidad de Sonora (in Spanish)

Nilsson DE, Gislen L, Coates MM, Skogh C, Garm A (2005) Advanced optics in a jellyfish eye. Nature 435:201-205

Nishikawa J, Thu NT, Ha TM, Thu PT (2008) Jellyfish fisheries in northern Vietnam. Plankton Benthos Res 3:227-234

Nishikawa J, Ohtsuka S, Mujiono N, Lindsay DJ, Miyamoto H, Nishida $S$ (2015) A new species of the commercially harvested jellyfish Crambionella from central Java, Indonesia with remarks on the fisheries. J Mar Biol Assoc UK 95:471-481

Ogimoto M, Suzuki K, Kabashima J, Nakazato M, Uematsu Y (2012) Aluminium content in foods with aluminium-containing food additives. Food Hyg Saf Sci 53:57-62 (in Japanese with English abstract)

Ohta N, Sato M, Ushida K, Kokubo M, Baba T, Taniguchi K, Urai M, Kihira K, Mochida J (2009) Jellyfish mucin may have potential disease-modifying effects on osteoarthritis. BMC Biotechnol 9:98

Oliveira OMP, Miranda TP, Araujo EM, Ayón P, Cedeño-Posso CM, Cepeda-Mercado AA, Córdova P, Cunha AF, Genzano GN, Haddad MA et al. (in press) Census of Cnidaria (Medusozoa) and Ctenophora from South American marine waters. Zootaxa

Omori M (1978) Zooplankton fisheries of the world: a review. Mar Biol 48:199-205

Omori M (1981) Edible jellyfish in the far east waters: a brief review of the biology and fishery. Bull Plankton Soc Jpn 28:1-111 (in Japanese with English abstract)

Omori M, Kitamura M (2004) Taxonomic review of three Japanese species of edible jellyfish. Plankton Biology Ecol 51:36-51

Omori M, Nakano E (2001) Jellyfish fisheries in southeast Asia. Hydrobiologia 451:19-26

Ovchinnikova TV, Balandin SV, Aleshina GM, Tagaev AA, Leonova YF, Krasnodembsky ED, Men'shenin AV, Kokryakov VN (2006) Aurelin, a novel antimicrobial peptide from jellyfish Aurelia aurita with structural features of defensins and channel-blocking toxins. Biochem Biophys Res Commun 348:514-523

Ozer NP, Celikkale MS (2001) Utilization possibilities of jellyfish Rhizostoma pulmo, as a food in the Black Sea. J Food Sci Technol 38:175-178

Page JW (2015) Characterization of bycatch in the cannonball jellyfish fishery in the coastal waters off Georgia. Mar Coast Fish 7:190-199

Palma S (2011) Las medusas de aguas chilenas y sus posibilidades de explotación comercial. Pontifica Universidad Católica de Valparaíso, Valparaiso, Chile, 5 pp (in Spanish)

Palomares MLD, Pauly D (2009) The growth of jellyfishes. Hydrobiologia 616:11-21

Panda SK, Madhu VR (2009) Studies on the preponderance of jellyfish in coastal waters of Veraval. Fish Technol 46:99-106

Pauly D, Christensen V, Dalsgaard J, Froese R, Torres F (1998) Fishing down marine food webs. Science 279:860-863 
Pauly D, Graham W, Libralato S, Morissette L, Palomares MLD (2009) Jellyfish in ecosystems, online databases, and ecosystem models. Hydrobiologia 616:67-85

Perl DP, Brody AR (1980) Alzheimer's disease-X-ray spectrometric evidence of aluminum accumulation in nerurofibrillary tangle-bearing neurons. Science 208:297-299

Prabhu MS (1954) The perch fishery by special traps in the area around Mandapam in the Gulf of Mannar and Palk Bay. Indian J of Fish 1:94-129

Prieto L, Astorga D, Navarro G, Ruiz J (2010) Environmental control of phase transition and polyp survival of a massiveoutbreaker jellyfish. PLoS One 5:e13793

Purcell J (2012) Jellyfish and ctenophore blooms coincide with human proliferations and environmental perturbations. Ann Rev of Mar Sci 4:209-235

Purcell JE, Arai MN (2001) Interactions of pelagic cnidarians and ctenophores with fish: a review. Hydrobiologia 451:27-44

Purcell JE, Uye S, Lo WT (2007) Anthropogenic causes of jellyfish blooms and their direct consequences for humans: a review. Mar Ecol Prog Ser 350:153-174

Quiñones J, Monroy A, Acha EM, Mianzan H (2013) Jellyfish bycatch diminishes profit in an anchovy fishery off Peru. Fish Res 139:47-50

Quiñones J, Mianzan H, Purca S, Robinson KL, Adams GD, Acha EM (2015) Climate-driven population size fluctuations of jellyfish (Chrysaora plocamia) off Peru. Mar Biol 162:2339-2350

Ranson G (1949) Resultats scientifiques des croisieres du navire-ecole belge "Mercator" IV. Méduses. Mémoires du Institut Royal des Sciences Naturelles de Belgique, Série 2:121-158

Reynaud AAM (1830) La Rhizostome (Méduse) rose. In: Lesson RP (ed) Centurie Zoologique, ou choix d'animaux rares, nouveaux ou imparfaitement connus. F.G. Levrault, Paris, pp 97-98, Pl. 34

Richardson AJ, Bakun A, Hays GC, Gibbons MJ (2009) The jellyfish joyride: causes, consequences and management responses to a more gelatinous future. Trends Ecol Evol 24:312-322

Ristroph L, Childress S (2014) Stable hovering of a jellyfish-like flying machine. J Royal Soc Interface 11:20130992

Roda A (2010) Discovery and development of the green fluorescent protein, GFP: the 2008 Nobel Prize. Anal Bioanal Chem 396:1619-1622

Rodriguez-Saenz K, Segura-Puertas L (2009) Hydrozoa, Scyphozoa, and Cubozoa (Medusozoa). In: Wehrtmann, I $\mathrm{S}$ and Cortes, J (eds) Marine Biodiversity of Costa Rica, Central America. Springer Science Business Media B.V. 94-100 (species list), Dordrecht, Netherlands, pp 143-149

Roux J-P, van der Lingen CD, Gibbons MJ, Moroff NE, Shannon LJ, Smith ADM, Cury PM (2013) Jellyfication of marine ecosystems as a likely consequence of overfishing small pelagic fishes: lessons from the Benguela. Bull Mar Sci 89:249-284

Rudloe J (1992) Jellyfish: a new fishery for the Florida Panhandle. Report prepared for The Apalachee Regional Planning Council, Blounstown, Florida, USA. US Department of Commerce, Economic Development Administration, EDA Project No. 04-06-03801, 35 pp
Ruiz J, Prieto L, Astorga D (2012) A model for temperature control of jellyfish (Cotylorhiza tuberculata) outbreaks: a causal analysis in a Mediterranean coastal lagoon. Ecol Model 233:59-69

Rumpet R (1991) Some aspects of the biology and fishery of jellyfish found along the coast of Sarawak, Malaysia. Department of Fisheries, Ministry of Agriculture, Malaysia, $53 \mathrm{pp}$

Sal Moyano MP, Schiariti A, Giberto DA, Briz LD, Gavio MA, Mianzan HW (2012) The symbiotic relationship between Lychnorhiza lucerna and Libinia spinosa in the Río de la Plata (Argentina-Uruguay). Mar Biol 159:1933-1941

Santhana-Krishnan G (1984) Salted jelly fish. Seaf Export J $16: 23-26$

Schiariti, A (2008) Life history and population dynamics of Lychnorhiza lucerna - an alternative fishery resource? Ph.D. thesis, Universidad de Buenos Aires (in Spanish)

Schiariti, A, Fuentes V, Mianzan H (2015) Pesquerías de medusas en Iberoamérica-¿Alternativa en tiempos de crisis? Investigación y Ciencia, 465 (in Spanish)

Schiariti A, Mianzan H (2013) La medusa Lychnorhiza lucerna como recurso pesquero alternativo en Argentina. Informe de Investigación No. 36 INIDEP. Área: Pesquerías Pelágicas y Ambiente Marino. Proyecto: Ecología Pesquera, Argentina, 9 pp (in Spanish)

Schiariti A, Kawahara M, Uye S, Mianzan HW (2008) Life cycle of the jellyfish Lychnorhiza lucerna. Mar Biol 156:1-12

Schiariti A, Christiansen E, Morandini AC, Silveira FL, Giberto DA, Mianzan HW (2012a) Reproductive biology of Lychnorhiza lucerna: individual traits related to sexual reproduction. Mar Biol Res 8:255-264

Schiariti A, Moyano MPS, Giberto DA, Mianzan HW (2012b) First record of the association between Lychnorhiza lucerna and Cyrtograpsus affinis. Latin Am J Aquat Res 40:1090-1093

Schiariti A, Morandini AC, Jarms G, Paes RG, Franke S, Mianzan H (2014) Asexual reproduction strategies and blooming potential in Scyphozoa. Mar Ecol Prog Ser 510:241-253

Schroeder R, Branco JO, Freitas F, Resgalla C (2014) Preliminary assessment of the jellyfish bycatch captured off southern and southeastern Brazil. Latin Am J Aquat Res 42:289-300

Seo J-I, Kim Y-R, Otsuki K, Kim S-W, Yeom K-J, Yi J-S, Ahn Y-S, Ezaki T, Chun K-W (2014) Contributions of jellyfish fertilizer to survival and growth of seedlings planted in a recently burned forest, Republic of Korea. J Fac Agric Kyushu Univ 59:181-189

Shamah D (2014) Israeli tech turns jellyfish into paper towels. Times of Israel, Jerusalem, Israel

Shih CT (1977) A guide to the jellyfish of Canadian Atlantic waters. National Museum of Natural Sciences,National Museums of Canada, Ottawa, Canada, 90 pp

Shimomura O (1995) A short story of aequorin. Biol Bull 189:1-5

Shimomura O (2005) The discovery of aequorin and green fluorescent protein. J Microsc 217:3-15

Silveira FL, Cornelius PFS (2000) New observations on medusae (Cnidaria, Scyphozoa, Rhizosomeae) from northeast and south Brazil. Acta Biol Leopold 22:9-18 (in Portuguese with English abstract) 
Sloan NA (1986) World jellyfish and tunicate fisheries, and the Northeast Pacific echinoderm fishery. Can Spec Publ Fish Aquat Sci 92:23-33

Sloan NA, Gunn CR (1985) Fishing, processing, and marketing of the jellyfish, Aurelia aurita [labiata], from southern British Columbia. Can Ind Rep Fish Aquat Sci 157:29

Soares MdO, Morandini AC, Matthews-Cascon H (2009) Neritic jellyfishes (Cnidaria: Cubozoa and Scyphozoa) from the coast of Rio Grande do Norte state, northeast of Brazil. Check List 5:133-138

Sommer U, Stibor H, Katechakis A, Sommer F, Hansen T (2002) Pelagic food web configurations at different levels of nutrient richness and their implications for the ratio fish production: primary production. Hydrobiologia 484:11-20

Soonthonvipat U (1976) Dried jelly fish. In: Tiews K (ed) Fisheries Resources and their management in Southeast Asia. Westkreuz-Druckerei, West Berlin, Germany, pp 149-151

Stiasny G (1920) Die Scyphomedusen-Sammlung des Naturhistorischen Reichs-museums in Leiden, III. Rhizostomeae. Zoologische Mededeelingen Leiden $5: 213-230$

Stiasny G (1922a) Ueber einige von Dr. C.J. van der Horst bei Curaçao gesammelte Medusen. Bijdragen tot de Kennis der Fauna van Curaçao Resultaten eener Reis van CJ van der Horst in 1920 23:83-91

Stiasny G (1922b) Papers from Dr. Th. Mortensen's Pacific Expedition 1914-1916. XIII. Die ScyphomedusenSammlung von Dr. Th. Mortensen nebst anderen Medusen aus dem Zooloigschen Museum der Universitat in Kopenhagen. Videnskabelige Meddelelser Nat For Kjobenhavn 73:513-555

Subasinghe S (1992) Jelly fish processing. INFOFISH Int 4:63-65

Suelo LG (1988) Utilisation of the Australian jellyfish Catostylus sp. as a food product. Diss Abstr Int B 48:3167-3168

Sweetman AK, Smith CR, Dale T, Jones DOB (2014) Rapid scavenging of jellyfish carcasses reveals the importance of gelatinous material to deep-sea food webs. Proc R Soc B 281:20142210

Templeman MA, Kingsford MJ (2010) Trace element accumulation in Cassiopea sp. from urban marine environments in Australia. Mar Environ Res 69:63-72

Thomas PA (1969) Goat fishes (Family Mullidae) of the Indian Seas. Marine Biological Association of India Memoirs III

Towanda T, Thuesen EV (2006) Ectosymbiotic behavior of Cancer gracilis and its trophic relationships with its host Phacellophora camtschatica and the parasitoid Hyperia medusarum. Mar Ecol Prog Ser 315:221-236

USDA (2015) National Nutrient Database for Standard Reference, Release 28. United States Department of Agriculture, Agricultural Research Service, Nutrient Data Laboratory, Washington, D.C., USA

Utne-Palm AC, Salvanes AGV, Currie B, Kaartvedt S, Nilsson GE, Braithwaite VA, Stecyk JAW, Hundt M, van der Bank M, Flynn B et al (2010) Trophic structure and community stability in an overfished ecosystem. Science 329:333-336

Valiela I, Bowen JL, York JK (2001) Mangrove forests: one of the world's threatened major tropical environments. Bioscience 51:807-815
Vanhöffen E (1888) Untersuchungen über semäostome und rhizostome Medusen. Bibliotheca Zoologica 1:5-52

Varghese M, Kasinathan C, Gandhi A (2008) Trap fishing in the Gulf of Mannar and Palk Bay. Marine Fisheries Information Service (197), Technical and Extension Series. Central Marine Fisheries Research Institute, Indian Council of Agricultural Research, Cochin, India, pp 7-8

Vehling JD (1977) Apicius-cookery and dining in imperial Rome. Dover Publications, Toronto, Canada, 301 pp

Verity PG, Smetacek V (1996) Organism life cycles, predation, and the structure of marine pelagic ecosystems. Mar Ecol Prog Ser 130:277-293

Wakabayashi K, Sato R, Ishii H, Akiba T, Nogata Y, Tanaka Y (2012) Culture of phyllosomas of Ibacus novemdentatus in a closed recirculating system using jellyfish as food. Aquaculture 330:162-166

Wang K (2007) The use of untraditional sea food: the commercialization of Norwegian jellyfish, red sea cucumber and whelk. SINTEF Report, Trondheim, Norway, 108 pp

Widersten B (1965) Genital organs and fertilization in some Scyphozoa. Zoologiska Bidrag från Uppsala 37:45-58

Wong WWK, Chung SWC, Kwong KP, Ho YY, Xiao Y (2010) Dietary exposure to aluminium of the Hong Kong population. Food Addit Contam Part A Chem Anal Control Expos Risk Assess 27:457-463

Wootton M, Buckle KA, Martin D (1982) Studies on the preservation of Australian jellyfish (Catostylus spp.). Food Technol Aust 34:398-400

Wu BL (1955) Rhopilema esculentum. Biol Bull 4:35-40 (in Chinese)

Yakovlev YM, Borodin PA, Osipov EV (2005) The fishery of jellyfish Rhopilema in Peter the Great Bay. Rybnoe Khozyaistvo 5:72-75 (in Russian)

Yang H, Shuang F (2015) Popular Chinese soups for clearing summer heat. Cook Knowl 7:36-47 (in Chinese)

Yin Q, Zhang D, Liu Y, Jiang N (2000) Study on processing technology of jellyfish. China Fish 27:46 (in Chinese)

You K, Ma CH, Gao HW, Li FQ, Zhang MZ, Qiu YT, Wang B (2007) Research on the jellyfish (Rhopilema esculentum) and associated aquaculture techniques in China: current status. Aquac Int 15:479-488

Yu HH, Liu XG, Xing RE, Liu S, Guo ZY, Wang PB, Li CP, Li PC (2006) In vitro determination of antioxidant activity of proteins from jellyfish Rhopilema esculentum. Food Chem 95:123-130

Zhang H, Zhang JY, Wang HL, Luo PJ, Zhang JB (2016) The revision of aluminum-containing food addidive provisions in China. Biomed Environ Sci 29:461-466

Zhong XM, Tang JH, Liu PT (2004) A study on the relationship between Cyanea nozakii breaking out and ocean ecosystem. Mod Fish Inf 19:15-17 (in Chinese)

Zhuang YL, Sun LP, Zhao X, Hou H, Li BF (2010) Investigation of gelatin polypeptides of jellyfish (Rhopilema esculentum) for their antioxidant activity in vitro. Food Technol Biotechnol 48:222-228

Zhuang Y, Sun L, Li B (2012a) Production of the angiotensin-Iconverting enzyme (ACE)-inhibitory peptide from hydrolysates of jellyfish (Rhopilema esculentum) collagen. Food Bioprocess Technol 5:1622-1629

Zhuang Y, Sun L, Zhang Y, Liu G (2012b) Antihypertensive effect of long-term oral administration of jellyfish 
(Rhopilema esculentum) collagen peptides on renovascular hypertension. Mar Drugs 10:417-426

Zimmer M (2005) Glowing genes: a revolution in biotechnology. Prometheus Books, Amherst, New York, USA, 221 pp
Zlotnick BA, Hintz S, Park DL, Auerbach PS (1995) Ciguatera poisoning after ingestion of imported jellyfish: diagnostic application of serum immunoassay. Wilderness Environ Med 6:288-294 